\title{
Birinci Dünya Savaşı'nda Amerikan Kütüphane Derneği'nin ABD Ordusuna Yönelik Hazırladığı Propaganda Posterleri Üzerine İnceleme
}

\author{
An Examination of the Propaganda Posters Prepared by the American Library \\ Association for the US Army During the First World War
}

\author{
Metin Işık*, Mehmet Ali Gazi**, Caner Çakı** ve Gül Çakı ${ }^{* * * *}$
}

$\ddot{\boldsymbol{O}} \boldsymbol{z}$

Birinci Dünya Savaşı'nda Amerikan Kütüphane Derneği (American Library Association/ ALA) liderliğinde kitap seferberliği başlatılmıştır. Bu seferberlik kapsamında hem ABD halkının kitap bağışı yapmalarının hem de ABD askerlerinin kitap okuma alışkanlı̆̆ kazanmalarının sağlanması için propaganda posterleri etkin bir şekilde kullanılmıştır. Amaç: Çalışmada ALA'nın kitlelerin kitap bağışı yapmalarında ve askerlerin kitap okumalarının teşvik edilmesinde propaganda posterlerini ne şekilde kullandı̆̆ının ortaya konulması amaçlanmıştır. Yöntem: Çalışmada nitel araştırma yöntemlerinden göstergebilim yöntemi kullanılmıştır. Çalışma kapsamında Birinci Dünya Savaşı'nda ALA tarafindan kullanılan propaganda posterleri Danimarkalı dilbilimci Louis Hjelmslev ve ABD dilbilimci William Labov'un göstergebilim modeli ışı̆̆ında analiz edilmiştir. Bulgular: Çalışmada elde edilen bulgularda kitap okumanın ABD askerleri için iyi bir boş zaman aktivitesi olduğuna ve bağışlanan kitapların ABD ordusunda verimli bir şekilde kullanıldı̆̆ına yönelik mesajların verildiği ortaya çıkarılmıştır. Sonuç: Çalışmada ALA'nın ABD halkının kitap bağışının ve askerlerin kitap okumasının teşvik edilmesi sürecinde askerlerin kitap okumaya istekli olduğuna yönelik algıyı posterler üzerinden oluşturmaya çalıştığ sonucuna ulaşılmıştır. Özgünlük: Ulusal literatür içerisinde ALA'nın bu bağlamdaki faaliyetlerini konu alan oldukça sınırlı çalışma bulunmaktadır. Çalışmada ALA'nın Birinci Dünya Savaşı özelinde faaliyetleri kapsamlı olarak incelenmeye çalışılmıştır.

Anahtar Sözcükler: Okuma alışkanlı̆̆l; Birinci Dünya Savaşı; propaganda; ABD.

\footnotetext{
* Sakarya Üniversitesi, Halkla İlişkiler ve Reklamcıllk Bölümü, Sakarya, Türkiye. E-posta: imetin@ sakarya. edu.tr

Sakarya University, Public Relations and Advertising Department, Sakarya,Turkey.E-mail: imetin@sakarya.edu.tr

${ }^{* *}$ Malatya Turgut Özal Üniversitesi, Görsel İletişim Tasarımı Bölümü. Malatya, Türkiye. E-posta: maligazi@gmail.com

Malatya Turgut Ozal University, Department of Visual Communication Design, Malatya, Turkey. E-mail: maligazi@gmail.com

*** İnönü Üniversitesi, İletişim Bilimleri ABD. Malatya, Türkiye. E-posta: caner.caki@inonu.edu.tr Inonu University, Department of Communication Sciences, Malatya,Turkey.E-mail: Caner.caki@inonu.edu.tr

**** Maltepe Üniversitesi, Halkla İlişkiler ve Reklamcılık ABD. İstanbul, Türkiye. E-posta: gulcaki06@hotmail.com

Maltepe University, Public Relations and Advertising Department, Istanbul, Turkey. E-mail:

gulcaki06@hotmail.com
}

Geliş Tarihi - Received: 05.04 .2021

Kabul Tarihi - Accepted: 27.05.2021

Yayımlanma Tarihi - Published: 30.06.2021 


\section{Abstract}

Book campaign was initiated during the First World War under the leadership of the American Library Association (ALA). Propaganda posters were used effectively to ensure that the US people donated books and the US soldiers gained the reading habit as part of this campaign. Objective: In the study, it was aimed to reveal how ALA used propaganda posters to encourage masses to donate books and also to promote soldiers to read books. Method: Semiotic method, which is one of the qualitative research methods, was used in the study. Within the scope of the study, the propaganda posters used by ALA during the First World War were analyzed in the light of the semiotics model of Danish linguist Louis Hjelmslev and US linguist William Labov. Findings: The findings of the study revealed that messages that reading books is a good leisure activity for US soldiers and that donated books are used efficiently in the US military were given. Implications: In the study, it was concluded that ALA tried to form the perception of soldiers' willingness to read books through posters in the process of encouraging the US people to donate books and soldiers to read books. Originality: There are very limited studies in the national literature on ALA's activities in this context. In the study, the activities of ALA specific to the First World War were tried to be examined comprehensively.

Keywords: Reading habit; World War I; propaganda; USA.

\section{Giriş}

ABD, 6 Nisan 1917 tarihinde Almanya'ya savaş ilan ederek İtilaf Devletleri'nin yanında Birinci Dünya Savaşı'na katılmıştır (Hart, 2018, s. 596). Savaşa dahil olunmasıyla birlikte ABD'de askeri ve ekonomik boyutta kapsamlı bir seferberlik başlatılmış ve ABD halkından savaşın kazanılması için ihtiyaç duyulan para ve iş gücü konusunda destek talep edilmiştir. $\mathrm{Bu}$ aşamada Amerikan Kütüphane Derneği (ALA) de savaş sırasında ABD askerlerini kitaplarla buluşturabilmek için ülkede kitap toplama seferberliği başlatmıştır. ALA bünyesinde halktan kitap toplanarak askeri kamp kütüphaneleri kurulmasına, bunlara personel temin edilmesine ve askeri hastanelerde kütüphane hizmetleri sağlanmasına odaklanılmıştır (Bertram, 2021, s. 2). Diğer yandan Birinci Dünya Savaşı sırasında ALA, ABD’de gerek yurt içindeki gerekse yurt dışındaki ABD askerlerinin kitap okuma alışkanlığı kazanmasını sağlayabilmek için çeşitli kampanyalar gerçekleştirmiştir. Gerçekleştirilen bu kampanyalar neticesinde ALA, ABD halkının desteğiyle kitaplar temin ederek, askerlerin ulaşabileceği yerlerde çeşitli kütüphaneler meydana getirmiştir. ALA tarafından meydana getirilen bu kütüphanelerle ABD askerlerinin boş zamanlarını kitap okuyarak geçirmeleri amaçlanmıştır. ALA gerçekleştirdiği kampanyalar sırasında gerek ABD halkının kitap bağışını teşvik etmek gerekse ABD askerlerinin kitap okuma alışkanlığı kazanmasını sağlamak için propaganda gerçekleştirmiştir. ALA'nın bu propaganda çalışmalarında da posterlerden sıkça yararlanılmıştır.

ALA'ya ilişkin literatür incelendiğinde ALA'yı konu alan çeşitli çalışmalara ulaşılmıştır (Olle, 1977; Brichford, 1991; Sullivan, 1996; Coolidge, 2005; Sanchez, 2005; Latham, 2010; Wiegand ve Wadsworth, 2010; Jankowska, 2011; Jones, 2015). Bu çalışmalar içerisinde: Young (1980), Birinci Dünya Savaşı ve ALA’nın genişletilmiş programını; Heim (1991), ALA içindeki yetişkin hizmetlerini; Martin ve Shiflett (1996), ALA ve siyahiler için kütüphane eğitimini; Maymí-Sugrañes (2002), Latin Amerika'daki ALA'y1; Preer (2004), ALA'nın 1936 Toplantısı'nı; Yee (2009), ALA, Kongre Kütüphanesi ve kart dağıtım 
programını; Williams vd. (2015), ALA bünyesinde sürdürülebilirlik topluluğu oluşturmayı; Wiegand (2017), ALA ve Amerika'nın güneyinde halk kütüphanelerini; Witt (2017) ALA içinde mahremiyetin evrimini; Sroka (2019), ALA ve İkinci Dünya Savaşı sonrası Doğu Avrupa kütüphanelerini incelemiştir.

ABD’deki kütüphaneler üzerine gerçekleştirilen çalışmaların dışında Birinci Dünya Savaşı'nda propaganda faaliyetlerini inceleyen de çeşitli akademik çalışmalar yapılmıştır (Demm, 1993; Smith, 2003; Redley, 2007; Sperry, 2014; Collins, 2015). Bu çalışmalarda da: Sanders (1975), Britanya propagandasını ve Wellington House'u; Shover (1975), Monger (2014), propaganda ve kadınları; Marquis (1978), İngiltere ve Almanya'da propaganday1; Taylor (1980), dışişleri bakanlığı ve İngiliz propagandasını; Messinger (1992), Britanya propagandasını; Messinger (1993), İngilizlerin resmi propagandaya yaklaşımını; Gullace (1997), İngiliz propagandası ve uluslararası hukuku; Monger (2012), vatanseverlik ve propaganday1; Tunc (2012), Amerikan propagandasın1; Robertson (2014), İngiliz ve Avustralya zulüm propagandasın1; Wilkin (2014), Fransa'da propagandayı; Fulwider (2017), Alman propagandasını ele almıştır.

ABD’nin Birinci Dünya Savaşı'ndaki savaş seferberliğinde kütüphane faaliyetlerini konu alan oldukça sınırlı çalışmaya ulaşılmıştır. Bu açıdan çalışma kapsamında ALA'nın Birinci Dünya Savaşı'nda gerçekleştirdiği kitap kampanyaları incelenerek, konuya ilişkin literatüre katkı sağlanması amaçlanmıştır. ALA'nın kampanyalar sırasındaki söylemleri propaganda amaçlı kullanılan posterler üzerinden incelenmiştir. Bu şekilde çalışmada ALA'nın propaganda posterleri üzerinden hem kitap bağışını hem de kitap okumayı teşvik etmek amacıyla hangi söylemlere yer verdiği ortaya konulmaya çalışılmıştır. ALA'nın propaganda posterlerindeki görsel ve yazılı kodlar üzerinden verdiği açık ve gizli mesajların ortaya konulabilmesi için propaganda posterleri göstergebilim yöntemi üzerinden analiz edilmiştir.

Çalışmada elde edilen bulgular ışığında aşağıdaki sorulara yanıt aranmaya çalışılmıştır:

- ALA'nın Birinci Dünya Savaşı'nda hazırlanan propaganda posterlerinde kitap bağışını teşvik etmede hangi görsel ve yazılı göstergelerden yararlanılmıştır?

- ALA'nın Birinci Dünya Savaşı'nda hazırlanan propaganda posterlerinde kitap okumanın teşvik edilmesinde hangi görsel ve yazılı göstergelerden yararlanılmıştır?

- ALA'nın Birinci Dünya Savaşı'nda hazırlanan propaganda posterlerinde ABD askerleri ne şekilde sunulmuştur?

- ALA'nın Birinci Dünya Savaşı'nda hazırlanan propaganda posterlerinde kitap okuma boyutunda hangi algılar oluşturulmaya çalışılmıştır?

Çalışmada elde edilen bulgular, Birinci Dünya Savaşı'nda ALA'nın kitap kampanyaları hakkında bilgi verilmesi, kitap kampanyalarında ABD halkına ABD askerlerinin ne şekilde sunulduğunun yansıtılması ve kitap okumanın teşvik edilmesinde ABD askerlerine yönelik hangi mesajların verildiğinin açıklaması bakımından önem taşımaktadır. 


\section{Birinci Dünya Savaşı’nda Amerikan Kütüphane Derneği’nin ABD Ordusundaki Kitap Seferberliği}

Amerikan Kütüphane Derneği (American Library Association, ALA), Amerika Birleşik Devletleri merkezli 57.000'den fazla üyesi bulunan kütüphaneleri ve kütüphane eğitimini uluslararası ölçekte teşvik eden, kâr amacı gütmeyen bir kuruluştur. ALA, 6 Ekim 1876 tarihinde Centennial Exposition'da kurulmuştur. Dernek, kütüphanecilerin mevcut işlerini daha kolay ve daha az masrafla yapmalarını sağlamak amacını taşımaktadır (ALA History, 2021). Diğer yandan ALA, bilgiye erişim eşitliğini tanımlama, genişletme, koruma ve savunma misyonunu da üstlenmektedir. ALA, kütüphaneler ve kütüphanecilikle ilgili olduğu düşünülen ABD'deki siyasi meselelerde ön plana da çıkabilmektedir.

ALA İcra Kurulu, daha sonra ismi Savaş Hizmeti Komitesi (War Service Committee) olacak olan Seferberlik ve Savaş Hizmeti Planları Komitesi'ni (Committee on Mobilizationand War Service Plans) görevlendirerek, yurtiçi ve yurtdışındaki askeri personele kitap ve süreli yayınlar sağlamayı üstlenmiştir. Başlangıçta, ALA iki büyük zorlukla karşılaşmıştır: kütüphaneler inşa etmek için fon oluşturmak ve bu kütüphaneler için kitap edinmek. Ülke çapındaki kütüphaneciler, tesislerde hizmet verme çağrısına olumlu cevap vermiş, bu açıdan personel sağlamak zor olmamıştır. Hatta birçok halk kütüphanesi ve akademik kütüphane, bu yeni oluşturulan ordu kütüphanelerinde hizmet vermeye gönüllü olurken kütüphanecilere ödeme yapmaya devam etmiştir (Andresen, 2010). Bu aşamada fon bulmak amacıyla kampanya yapılmıştır. İlk kampanyada kamp kütüphaneleri için 1 milyon dolar toplanmış ve bir kitap gezisi de meydana getirilmiştir. Kampanyalarda ABD halkından "bir kitap için bir dolar" talep edilmiş, bunun yanında ABD askerleri için ABD halkından doğrudan kitap ve dergiler toplanmıştır. Ayrıca komite, Savaş Bakanlığı Eğitim Kampı Faaliyetleri Komisyonu'nun (War Department's Commission on Training Camp Activities) Amerika, Fransa ve diğer yerlerdeki ABD askerlerine ve denizcilere kütüphane hizmeti sağlama davetini kabul etmiş ve çalışma yürütmüştür. Dernek, komisyona bağlı yedi sosyal yardım grubundan biri olmuştur. ALA'nın Kütüphane Savaş Servisi (Library War Service, LWC) olarak bilinen savaş zamanı programları, kongre kütüphanecisi Herbert Putnam ve daha sonra Carl H. Milam tarafından yönetilmiştir. 1917 yılında ALA’nın üyeliği 3.300'ün üstünde olmuştur. LWC, 1917 yılında ALA tarafından kamplarda eğitim gören ve Birinci Dünya Savaşı'nda denizaşırı ülkelerde hizmet veren Amerikan askerlerine kütüphane hizmetleri sağlamak için kurulmuştur (Library War Service, 2021).

Birinci Dünya Savaşı sırasında LWC, ALA'nın ilk büyük girişimi olmuştur (American Library Association Archives, 2021). ALA, 1917-1920 yılları arasında çeşitli faaliyetler gerçekleştirmiştir. Bu dönemde ALA, iki kampanya düzenlemiş ve kamu bağışlarından 5 milyon dolar toplamış, Carnegie Corporation fonlarından 320.000 ABD Doları ile otuz altı kamp kütüphanesi kurmuş, yaklaşık 7-10.000.000 kitap ve dergi dağıtmış, askeri hastaneler de dahil olmak üzere 500 'den fazla yere kütüphane materyali sağlamıştır. Derneğin sponsor olduğu kütüphanelerde yaklaşı 1.200 kütüphane çalışanı görev yapmıştır. LWC'nin çalışmalarında, ordu, donanma ve gazi bürosunda kalıcı kütüphane bölümleri oluşturulmuştur. İlk olarak 1918 yılında kurulan, ancak savaşın sonunda 1920 yılında resmi olarak faaliyetini sürdüren Paris'te Amerikan Kütüphanesi (The American Library in Paris) kurulmuştur. Ayrıca derneğin uluslararası ilişkiler ve yetişkin eğitimi alanlarındaki faaliyetleri teşvik edilmiştir 
(Library War Service, 2021). ALA'nın himayesinde kurulan Paris'teki Amerikan Kütüphanesi, Amerikan kütüphaneleri tarafından Birinci Dünya Savaşı'nda Birleşik Devletler silahlı kuvvetleri personeline bağışlanan kitap ve süreli yayınlardan oluşan çekirdek bir koleksiyonla meydana getirilmiştir (ALIP, 2021).

ALA tarafindan tasarlatılan kütüphanelerin her birinde yaklaşık 14.000 kitap yerleştirmek için raflı büyük bir oda ve kütüphaneciler için yaşam alanları yer almıştır. Tam donanımlı olduklarında, kütüphaneler bir seferde 225 okuyucuyu ağırlayabilmiştir. Kitaplar genel olarak ülke çapındaki diğer kütüphanelerden, yazarlardan, yayıncılardan ve savaş çabalarına küçük bir şekilde katkıda bulunmak isteyen bireylerden hediye olarak gelmiştir (Andresen, 2010).

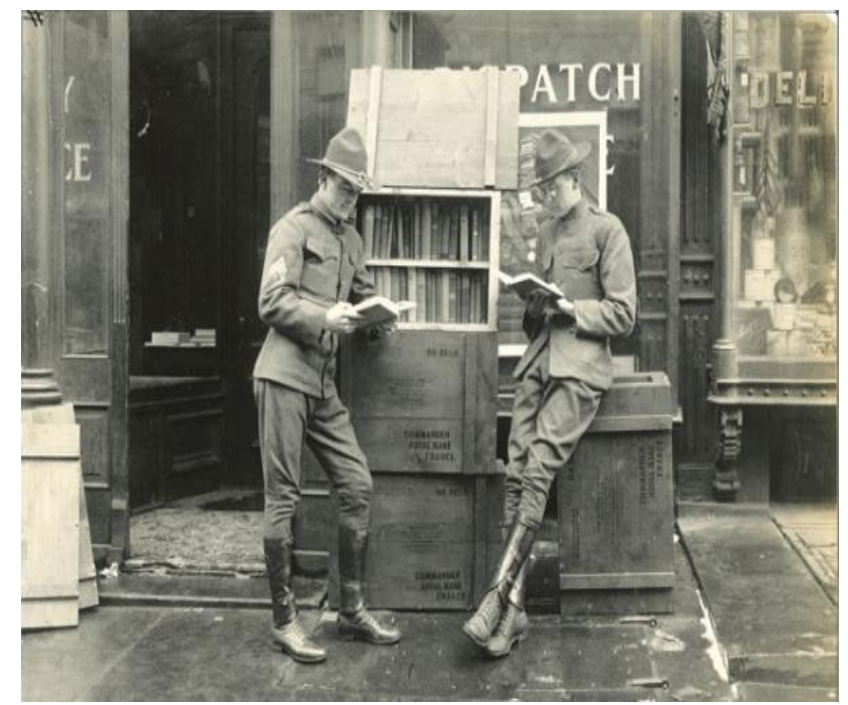

Görsel 1. Birinci Dünya Savaşı'nda Ateşkesten Hemen Sonra Paris'teki Amerikan Askerleri (Kniffel, 2020).

ALA, Birinci Dünya Savaşı'nda görev yapan askerlere ve denizcilere kütüphane hizmeti sağlamada aktif bir rol oynamış, bu hizmetin çoğu, ALA tarafından Kütüphane Savaş Servisi'ni duyurmak için üretilen resimli kartpostallar ve posterlerde belgelenmiştir (LHB, 2021). ALA'nın faaliyetlerinin reklamı amaciyla hazırlanan kartpostallarda kütüphanelerin görsellerine yer verilmiştir. Örneğin hazırlanan kartpostallardan birinde Teksas, Kelly Field'daki ALA Kamp Kütüphanesi ve Almanya'da Koblenz'de hastane kütüphanesi de yer almıştır. ALA sayesinde askerler kamp kütüphanesinde, denizciler gemide ve hastalar da hastanede kitap okuma imkânı bulmuştur. 


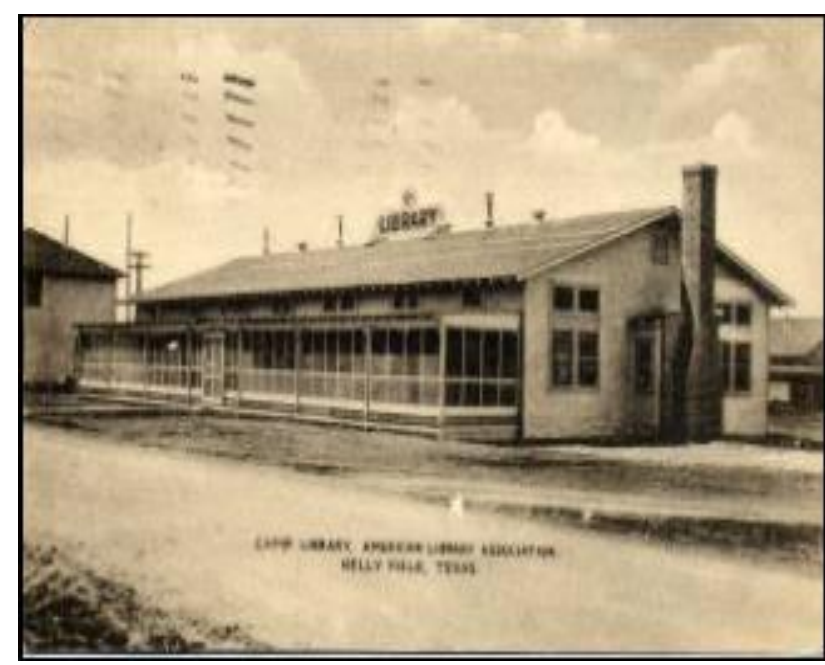

Görsel 2. Teksas, Kelly Field'daki ALA Kamp Kütüphanesi (LHB CL, 2021).

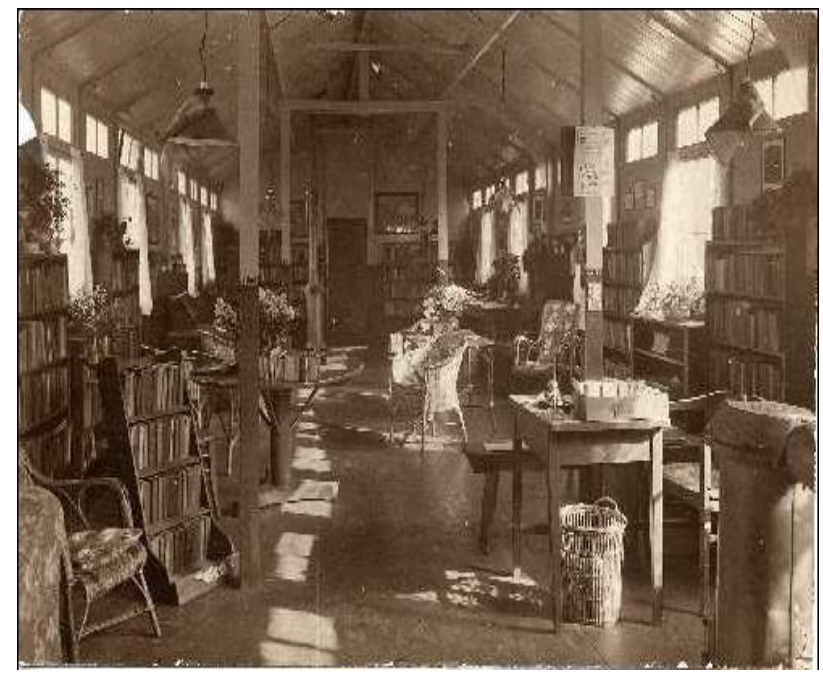

Görsel 3. Almanya'da Koblenz’de Hastane Kütüphanesi (LHB H, 2021).

Fon toplamanın başarısı, posterlerin, kitapçıkların ve basın bültenlerinin dağıtımını içeren ve çeşitli askeri görevlerde kütüphanelere olan temel ihtiyacı vurgulayan ülke çapında bir tanıtım kampanyasından kaynaklanmıştır. 1918'in başlarında başlatılan eşit derecede başarılı bir fon toplama kampanyası, 3 milyon dolardan fazla toplamış ve böylece 11 Kasım 1918 tarihindeki ateşkesten sonra yeni kurulan kütüphanelerin varlığını sürdürmesini sağlamıştır. Savaş sona ermeden önce, ALA ve diğer kuruluşlar yaklaşık 860 ordu, donanma ve deniz piyadeleri tesislerine, 208 hastaneye ve 911 gemiye kütüphane hizmeti sağlamıştır. $\mathrm{Bu}$ kütüphane tesisleri, savaş zamanında Amerikan Silahlı Kuvvetleri için kilit bir moral faktörü olduğunu kanıtlayan yaklaşık 10 milyon kitap, dergi, gazete ve süreli yayına erişim sağlamıştır (Andresen, 2010).

Günümüzde ALA, amacını kütüphane hizmetini ve kütüphaneciliği teşvik etmek olarak belirmektedir. Öğrenmeyi geliştirmek ve herkes için bilgiye erişimi sağlamak için kütüphane ve bilgi hizmetlerinin ve kütüphanecilik mesleğinin geliştirilmesi, tanıtımı ve iyileştirilmesi için liderlik sağlamak da misyon olarak açıklanmaktadır (ALA Mission, 2021). ALA'nın faaliyetleri, bir dizi yönetim belgesi tarafından şekillendirilmekte ve yönlendirilmektedir. Birliğin ilk resmi belgesi, 1942'de revize edilen 1879 Tüzüğü'dür. ALA'nın yapısı ve İç Tüzüğü, ALA Konseyi tarafından onaylanmakta ve üyeler tarafından 
oylanmaktadır. ALA başkanı, birliğin baş sözcüsü olmakta ve ulusal ve uluslararası kütüphane konularının belirlenmesi ve tanıtılmasında ALA'nın icra direktörü ile yakın işbirliği içinde çalışmaktadır. ALA Başkanı, üyeleri tarafından birliğin lideri olarak kabul edilmektedir (ALA Governance, 2021). ALA çalışmalarını üyeler tarafından yönlendirilen komiteler ve alt komiteler, bölümler, yuvarlak masalar ve diğer çeşitli grup türleri aracılığıyla yürütmektedir. Her komitenin kurulduğu anda tanımlanan belirli bir amacı vardır. Her bölüm ve yuvarlak masa, bölünme veya yuvarlak masa çalışmalarını yürütmek için komiteler ve diğer çalışma grupları oluşturabilmektedir (ALA Committees, 2021).

\section{Birinci Dünya Savaşı'nda ABD'nin Posterleri Propaganda Amaçlı Kullanımı ve ALA}

Propaganda, en basit tanımıyla belirli bir fikrin kitlelere kabul ettirilmesi amaciyla gerçekleştirilen bir iletişim tekniğidir. Propagandacı, kitle iletişim araçlarından yararlanarak hedef kitlesini istediği düşünce çerçevesinde ikna etmeye çalışmaktadır. Propaganda, ekonomiden siyasete, sanattan eğitime pek çok farklı alanda kullanılabilmektedir. Diğer yandan propaganda sürecinde pek çok farklı kitle iletişim aracından da yararlanılabilmektedir. Bunlardan biri de posterlerdir. Posterlerden propaganda amaçlı yararlanıldığında kullanıcısına pek çok avantaj sağlayabilmektedir. Posterlerdeki görseller üzerinden herhangi bir durum istenildiği gibi kitlelere aktarılabilmektedir. Yine propagandacının desteklediği bir kişi poster üzerinden daha güçlü bir şekilde yüceltilerek resmedilebilmektedir. Okuma yazma bilmeyen (veya posterdeki dili bilmeyen) kişilere propaganda mesajı posterlerdeki görseller üzerinden aktarılabilmektedir. Posterlerde kullanılan farklı diller üzerinde de posterlerdeki propaganda mesajı uluslararası bir özellik kazanabilmektedir (Işık ve Karaca, 2019, s. 46). Tüm bu özellikler Birinci Dünya Savaşı'nda posterlerin propaganda amaçlı sık kullanılmasını sağlamıştır.

ABD, Birinci Dünya Savaşı'nda posterlerden propaganda amaçlı etkin bir şekilde yararlanan ülkelerden biri olmuştur. Özellikle Kaти Bilgilendirme Komitesi (Committee on Public Information, CPI), Birinci Dünya Savaşı'nda posterlerden propaganda amaçlı yararlanma konusunda ön plana çıkmıştır. Komite, ABD'nin savaşa dahil olmasından kısa bir süre sonra 14 Nisan 1917 tarihinde propaganda faaliyetine başlamış ve savaşın bitmesinden sonra bir süre daha faaliyetlerini sürdürmüştür. CPI, savaş çabalarına destek sağlamak için bağımsız bir bilgi ajansı olarak kurulmuştur (Wang, 2007, s. 23). Savaşan tüm hükümetler propagandaya yoğun bir şekilde yatırım yapsa da, ABD hükümeti propagandası, hem operasyonlarının niteliği hem de genişliği açısından CPI'nın kontrolü altına aldığı için ayırt edici bir özellik taşımıştır (Fischer, 2016, s. 51). CPI'nin faaliyetlerinde ABD halkının savaş çabalarına katkı sağlamaları amaçlanmış bu aşamada ABD vatandaşlarına vatanseverlik vurgusu yapan mesajlar aktarılmıştır. CPI gerçekleştirdiği propaganda faaliyetlerinde çeşitli kitle iletişim araçlarından yararlanmıştır. Bunlar içerisinde özellikle posterler kitlelerin istenilen yönde ikna edilmesinde önemli bir propaganda aracı olarak kullanılmıştır. Savaş sırasında hazırlanan propaganda posterleri kitlelerin dikkatini çekebilecek yerlere asılmış ve insanların birkaç saniyeliğine de olsa posterlerdeki propagandaya maruz kalmasına çalışılmıştır. Propaganda posterlerinde ABD halkının savaşın kazanılmasında savaş çabalarına verecekleri desteğin önemi vurgulanmıştır. 
Birinci Dünya Savaşı'nda posterler, propagandanın dışında gazete okumayan, toplantılara katılmayan ve film izlemeyen ABD vatandaşları için önemli bir haber kaynağı niteliği taşımıştır. Bu açıdan posterlerde çeşitli propaganda mesajları verilirken aynı zamanda savaş sırasında yaşanan gelişmeler hakkında da bilgi verilmiştir. Örneğin ALA'nın kitap bağışı kampanyasının kitlelere duyurulmasında posterler ön plana çıkarılmıştır. Propaganda posterlerinin bir diğer özelliği posterdeki göstergeler üzerinden çeşitli düzenlemelerin yapılabilmesidir. Örneğin olumsuz şekilde gösterilmek istenen kişiler posterdeki görselde tehlikeli olarak yansıtılabilmektedir (Avcı ve Çak1, 2020, s. 105). Birinci Dünya Savaşı'nda ABD'de Almanya'yı hedef alan kimi propaganda posterinde de Alman askerleri korkutucu biçimde resmedilmiştir. Bu şekilde ABD kamuoyunda Almanya karşıtı algı güçlendirilerek ABD halkının savaş çabalarına destek olmaları amaçlanmıştır. Ayrıca ABD halkının savaş bonolarını satın alması sürecinde de posterden propaganda amaçlı yararlanılmış, bu propaganda posterlerinde vatanseverlik kavramı ön plana çıkarılmıştır. Genel olarak değerlendirildiğinde Birinci Dünya Savaşı'nda taraflar arasında söz savaşı yaşanmış (Marquis, 1978, s. 467), bu söz savaşında da ABD propaganda posterlerinden etkin bir şekilde yararlanmıştır.

ABD'de propaganda posterleri siyasi kullanımının dışında kütüphanecilik alanında da ön plana çıkmıştır. Birinci Dünya Savaşı özelinde değerlendirildiğinde ALA, kütüphanecilik alanında posterlerden propaganda amacıyla etkin bir şekilde yararlanmıştır. $\mathrm{Bu}$ aşamada hazırlanan posterler üzerinden ABD halkının zihninde kitap bağışının önemine yönelik algılar oluşturarak, Birinci Dünya Savaşı'nda ABD halkını ABD ordusu için kitap bağışı yapmaya ikna etmeye çalışmıştır. Ayrıca posterlerde kitap okumanın önemine yönelik ABD askerlerine propaganda gerçekleştirmiştir. ALA, posterler üzerinden ABD askerlerine kitap okumay1 sevdirmeye ve kitap okuma alışkanlığı kazandırmaya çalışmıştır. Savaşın zor şartlarının yol açtığı ekonomik sıkıntılara rağmen ABD halkından kitap bağışı konusunda ekonomik yönden fedakârlıkta bulunmasını istenmiştir. Bu aşamada ALA, propaganda posterleri üzerinden gerçekleştirdiği propagandayla ABD halkının bu fedakârlığ gerçekleştirmesine çalışmıştır. Diğer yandan savaş atmosferi içerisinde askerlerin boş zamanlarını kitap okuyarak geçirmelerinin teşvik edilmesinde de ALA yine posterlerdeki propaganda mesajlarından yararlanmıştır. Tüm bu süreç savaş sırasında kütüphanecilik faaliyetlerinin gerçekleştirilmesinde propagandanın önemine vurgu yapmaktadır.

\section{Yöntem}

Çalışmada gerçekleştirilen inceleme sonucunda Hoover Enstitüsü Kütüphanesi ve Arşivleri'nden (Hoover Institution Library and Archives) ALA'yla ilişkili toplam 112 postere ulaşılmıştır. 112 poster içerisinde 96 tanesi Birinci Dünya Savaşı, 6 tanesi ise İkinci Dünya Savaşı sırasında hazırlanmıştır. İkinci Dünya Savaşı'ndaki 6 poster ve Yidiş dilindeki 1 poster çalışmanın dışında tutulmuştur. Çalışma kapsamında 95 poster konu ve içerik bakımından incelenmiş ve posterlerin 51 tanesinin bağış, 35 tanesinin bilgilendirme ve 9 tanesinin ise kitap okumayı teşvik eden içeriği olduğu ortaya konulmuştur. Bilgilendirme boyutundaki 35 propaganda posterinin kitaplarla ilgili genel bilgi vermesi nedeniyle, çalışmada ALA'nın bağış ve kitap okunmasını teşvik eden posterleri üzerine inceleme gerçekleştirilmiştir. Çalışma kapsamında tarih, kurum ve içerik üzerinden amaçlı örneklem metodu kullanılarak bağış konulu posterler içerisinden 5 ve kitap okumayı teşvik eden posterler içerisinden de 5 
poster çalışma kapsamında örneklem olarak belirlenmiştir. Çalışmanın örneklemi belirlenirken posterlerin doğrudan kitap bağışını ve kitap okuma alışkanlığını teşvik eden posterler olmasına dikkat edilmiştir. Ayrıca yalnızca yazılı göstergelerin kullanıldığı posterler çalışmanın dışında tutulmuştur. Çünkü posterlerde hem görsel hem de yazılı göstergeler üzerinden verilmek istenen mesajın kitleler üzerinde daha etkili olabileceği düşünülmüştür. Çalışmada hem görsel hem de yazılı göstergelere yer veren posterler çalışmanın örneklemi olarak belirlenmiştir. Diğer yandan örneklem belirlenirken benzer içerikleri olan posterler çalışmada elenmiş, sonuç olarak kalan 5'er poster çalışmada analiz edilmiştir.

Çalışma kapsamında örneklem olarak belirlenen 10 propaganda posteri, nitel araştırma yöntemlerinden biri olan göstergebilim yöntemi kullanılarak incelenmiştir. Göstergebilim, göstergeleri ve onların çalışma biçimlerini incelemektedir (Fiske, 2017, s. 122). Son yıllarda posterler üzerinden kütüphane ve okuryazarlığı konu alan çeşitli ulusal çalışmalar gerçekleştirilmiştir (Aladağ, 2019; Çakı vd., 2020; Gazi vd., 2020; Gazi vd., 2021). Bu çalışmalarda Roland Barthes, Roman Jakobson ve Charles William Morris gibi dilbilimcilerin göstergebilim anlayışlarından yararlanılmıştır. Bu çalışmada ise posterlerde yer alan yazılı ve görsel göstergeler Danimarkalı dilbilimci Louis Hjelmslev ve ABD dilbilimci William Labov'un göstergebilim anlayışı 1şı̆̆ında analiz edilmiştir. Göstergebilim alanında Ferdinand de Saussure (Çakı vd., 2017, s. 74), Charles William Morris (Gülada, 2019, s. 334; Dündar, 2020, s. 338) ve Karl Bühler (Baytimur, 2020, s. 82) gibi uzmanların göstergebilim anlayışları kullanılarak çeşitli çalışmalar yapılmıştır. Çalışmada ise Hjelmslev’in göstergebilim anlayışı, posterlerdeki göstergelerin dizimlenmeleri üzerinden hangi anlamların ortaya konulduğunu açıklamak ve Labov'un göstergebilim anlayışı da posterlerdeki içeriği kapsamlı olarak analiz edebilmek için tercih edilmiştir.

Hjelmslev'in göstergebilim analizinde göstergeler dört boyutta (anlatımın tözü, anlatımın biçimi, içeriğin tözü, içeriğin biçimi) incelenmektedir (Rifat, 2013, s. 118). Anlatımın tözü, göstergelerin belirli bir anlam bütünü oluşturulmak için bir araya getirilmeden önceki durumunu ifade etmektedir. Anlatımın biçimi ise göstergelerin belirli bir anlam bütünü oluşturmak amacıyla kullanımını açıklamaktadır. İçeriğin tözü, iletişim sürecinde göstergenin taşıdığı anlamı ifade etmektedir. İçeriğin biçimi, belirli anlamlar oluşturma amacıyla bir araya getirilen göstergeler üzerinden yansıtılan mesajları açıklamaktadır. Labov'un göstergebilim çözümlemesinde ise altı boyut (soyutlama, konumlandırma, eyleme geçme, çözüm, düşünüm, koda) kullanılmaktadır. Soyutlama, metinde geçen temel amacı ifade etmektedir. Konumlandırma, metnin bağlamını açıklamaktadır. Eyleme geçme, metinde vurgu yapılan, ön plana çıkarılan durumu ifade etmektedir. Çözüm, metinde yapılan son açıklamadır. Düşünüm, verilen ana mesajı ifade etmektedir. Koda, metinde daha sonra uygulanması amaciyla ortaya konulan çıkarımı açıklamaktadır. Çalışmada Hjelmslev ve Labov'un göstergebilim kavramları dışında aynı zamanda propaganda posterlerinde mitler, metonimiler, metalepsisler, sinekdoşlar, metaforlar ve simgeler üzerinden propaganda mesajlarının ne şekilde inşa edildiği de ortaya konulmaya çalışılmıştır. 


\section{Bulgular ve Yorum}

Çalışmada propaganda posterlerindeki görsel ve yazılı göstergeler, ilk olarak Hjelmslev'in ardından da Labov'un göstergebilim anlayışları ışı̆̆ında analiz edilmiştir.

\section{Kitap Bağışını Teşvik Eden Propaganda Posterleri}

Çalışmanın bu kısmında kitap bağışını teşvik eden para, zihin, hediye, dolar ve kartal konulu posterler incelenmiştir.

\section{“Para” Konulu Propaganda Posteri}

Arkadaş konulu propaganda posteri, 1917-1918 yılları arasında tarihlenmektedir. Anlatımın tözü boyutunda incelendiğinde posterde askerler ve kitaplar yer almaktadır. Anlatımın biçimi üzerinden ele alındığında posterde bir askerin kitap okuması, diğer askerin kitapları tutması gösterilmektedir. İçeriğin tözü boyutunda incelendiğinde posterde okuma isteği ve kitap yardımı mesajları verilmektedir. İçeriğin biçimi üzerinden ele alındığında posterde ABD askerlerinin okumaya istekli olması ve askerlere kitap desteğinin teşvik edilmesi ön plana çıkarılmaktadır.

\section{Tablo 1}

Hjelmslev'in Modeli Üzerinden Para Konulu Propaganda Posterinin Analizi

Anlatımın Tözü $\quad$ Askerler ve kitaplar

Anlatımın Biçimi $\quad$ Bir askerin kitap okuması, diğger askerin kitapları tutması
İçeriğin Tözü
Okuma isteği, kitap yardımı

İçeriğin Biçimi $\quad$ ABD askerlerinin okumaya istekli olması ve askerlere kitap desteğinin teşvik edilmesi

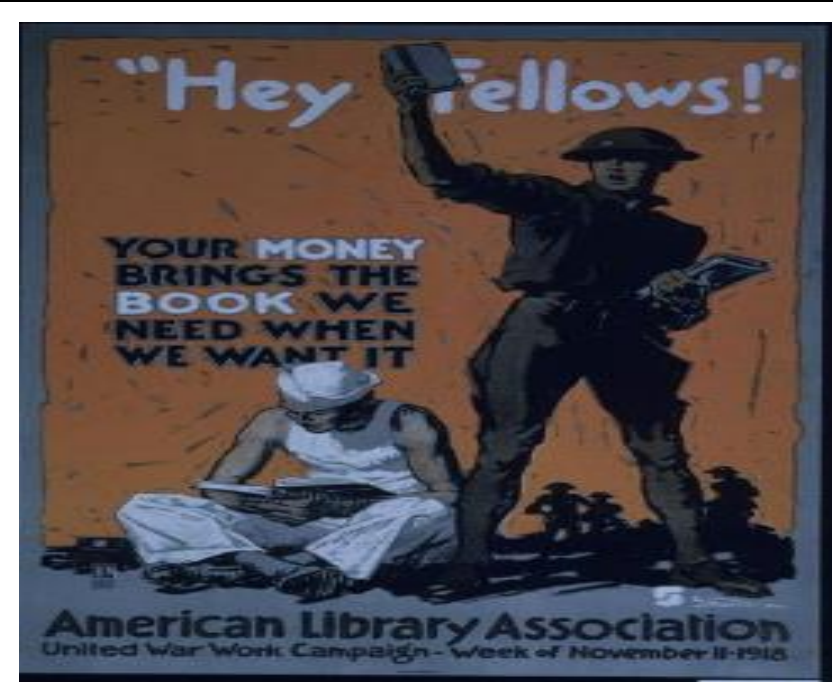

Poster 1. Para Konulu Propaganda Posteri ${ }^{1}$ (Hoover Institution, 2021a).

\footnotetext{
${ }^{1}$ Posterde, "Hey arkadaşlar!" Paranız istediğimiz zaman ihtiyacımız olan kitabı getiriyor, Amerikan Kütüphane Derneği, Birleşik Savaş Çalışma Kampanyası, Kasım Haftası 111918 yazısı bulunmaktadır.
} 
Soyutlama boyutunda posterde kitap yardımı konu alınmaktadır. Posterin arka planından konumlandırma açısından posterdeki kişilerin karargâhta (ya da kışlada) olduğuna yönelik algı oluşturulmaktadır. Posterdeki askerin kitabı havaya kaldırması eyleme geçme boyutunu yansıtmaktadır. Kitap talebi posterdeki çözüm boyutudur. Askerlerin kitaplara ihtiyaç duyması ise düşümünü açıklamaktadır. Koda açısından ABD halkının kitap yardımı yapması gerektiği aktarılmaktadır. Genel olarak değerlendirildiğinde posterde ABD askerlerinin kitap okumayı sevdiğine yönelik mesaj verilmeye çalışılmaktadır. Posterde denizci üniforması içerisindeki asker, ABD deniz kuvvetlerindeki askerlerin, kitabı havaya kaldıran asker ise ABD kara kuvvetlerindeki askerlerin metonimi olarak kullanılmaktadır. Böylece ABD'de hem kara hem de deniz kuvvetlerindeki askerlerin boş zamanlarında kitap okuduğu düşüncesi meydana getirilmektedir. Çalışma kapsamında incelenen diğer posterlerdeki askerler de doğrudan $\mathrm{ABD}$ askerlerinin metonimi olarak kullanılmaktadır. Askerlerin elindeki kitaplar, diğer posterlerde olduğu gibi ABD halkının ABD ordusuna yaptığı kitap yardımının sinekdoşu olarak kullanılmaktadır. Bu aşamada askerin okuduğu kitabı doğrudan ABD halkının ABD askerlerine yaptığı kitap yardımlarından temin ettiğine yönelik algı oluşmaktadır. Posterdeki yazılı kodlar üzerinde de kitap yardımını doğrudan ABD askerlerinin istediğine yönelik algı oluşturulmaktadır.

\section{Tablo 2}

Labov'un Modeli Üzerinden Para Konulu Propaganda Posterinin Analizi

\begin{tabular}{cccccc}
\hline Soyutlama & Konumlandırma & Eyleme Geçme & Çözüm & Düşünüm & Koda \\
Kitap & Karargâh/kışla & $\begin{array}{c}\text { Askerin kitabı } \\
\text { havaya kaldırması }\end{array}$ & $\begin{array}{c}\text { Kitap } \\
\text { talebi }\end{array}$ & $\begin{array}{c}\text { Askerlerin kitaplara } \\
\text { ihtiyacı olduğu }\end{array}$ & $\begin{array}{c}\text { ABD halkının kitap } \\
\text { yardımı yapması } \\
\text { gerektiği }\end{array}$ \\
\hline
\end{tabular}

\section{Zihin Konulu Propaganda Posteri}

Zihin konulu propaganda posteri, 1917-1918 yılları arasında tarihlenmektedir. Anlatımın tözü üzerinden ele alındığında posterde askerler, binalar ve kitap resmedilmektedir. Anlatımın biçimi boyutunda incelendiğinde posterde bir askerin kitap okuması, diğer askerin binaların önünde nöbet tutması gösterilmektedir. İçeriğin tözü üzerinden ele alındığında posterde kitap yardımı mesajı verilmektedir. İçeriğin biçimi boyutunda incelendiğinde posterde askerlerin boş zamanlarında kitap okumasının istenmesi ve kitap yardımının teşvik edilmesi ön plana çıkarılmaktadır.

Tablo 3

Hjelmslev'in Modeli Üzerinden Zihin Konulu Propaganda Posterinin Analizi

\begin{tabular}{cc}
\hline Anlatımın Tözü & Askerler, binalar ve kitap \\
\hline Anlatımın Biçimi & Bir askerin kitap okuması, diğer askerin binaların önünde nöbet tutması \\
İçeriğin Tözü & Kitap yardımı \\
İçeriğin Biçimi & Askerlerin boş zamanlarında kitap okumasının istenmesi ve kitap \\
yardımının teşvik edilmesi
\end{tabular}




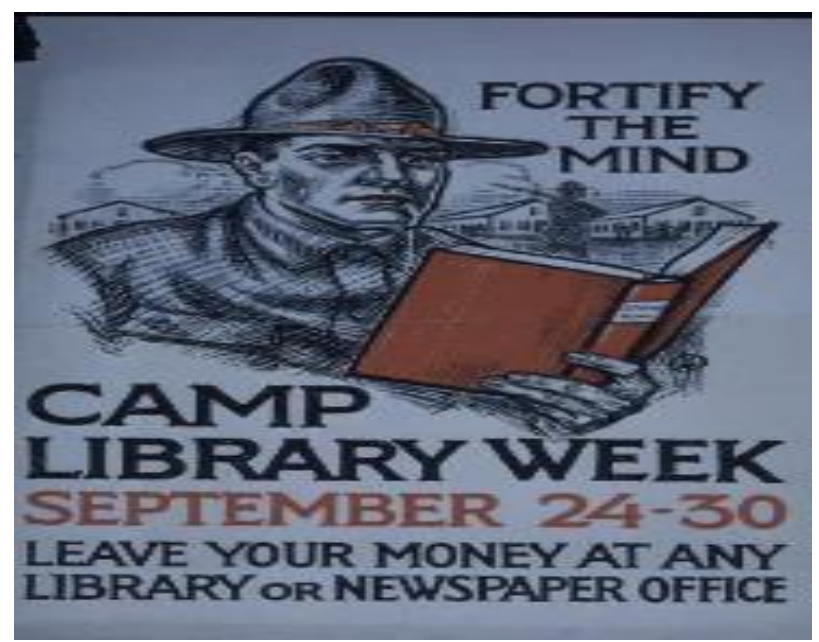

Poster 2. Zihin Konulu Propaganda Posteri² (Hoover Institution, 2021b).

Soyutlama açısından kitap yardımına vurgu yapılmaktadır. Konumlandırma boyutunda posterin arka planından posterdeki kişilerin karargâhta (ya da kışlada) olduğu algısı meydana gelmektedir. Posterdeki askerin kitap okuması eyleme geçme boyutunu yansıtmaktadır. Çözüm boyutunda kitap yardımı için para bırakılması gerektiği aktarılmaktadır. Düşünüm açısından askerlerin boş zamanlarında kitap okuduğu mesajı verilmektedir. Koda boyutunda ABD halkının kitap yardımı yapması gerektiği vurgulanmaktadır. Genel olarak değerlendirildiğinde posterde bir askerin nöbet tutması, diğer askerin ise kitap okumasıly ABD askerlerinin boş zaman aktivesi olarak kitap okumayı tercih ettiğine yönelik mesaj verilmektedir. Poster üzerinden ABD askerlerinin boş zamanlarında kitap okuyabilmesi için ABD halkının kitap bağışı yapması teşvik edilmektedir.

Tablo 4

Labov'un Modeli Üzerinden Zihin Konulu Propaganda Posterinin Analizi

\begin{tabular}{cccccc}
\hline Soyutlama & Konumlandırma & Eyleme Geçme & Çözüm & Düşünüm & Koda \\
Kitap & \multirow{2}{*}{ Karargâh/kışla } & Askerin kitap & Kitap yardımı & Askerlerin boş & ABD halkının \\
yardımı & okuması & için para & zamanlarında kitap & kitap yardımı \\
& & & bırakılması & okuduğu & yapması gerektiği \\
\hline
\end{tabular}

\section{Hediye Konulu Propaganda Posteri}

Hediye konulu propaganda posteri, 1917-1918 yılları arasında tarihlenmektedir. Anlatımın tözü boyutunda incelendiğinde posterde bir asker ve kitaplar resmedilmektedir. Anlatımın biçimi üzerinden ele alındığında posterde askerin sıraya dizilmiş kitapları taşıması gösterilmektedir. İçeriğin tözü boyutunda incelendiğinde posterde kitap ihtiyac1 vurgulanmaktadır. İçeriğin biçimi üzerinden ele alındığında posterde ABD askerlerine kitap yardımının teşvik edilmesi mesajı verilmektedir.

\footnotetext{
${ }^{2}$ Posterde, Zihni güçlendirin. Kamp Kütüphanesi Haftasl, 24-30 Eylül. Paranızı herhangi bir kütüphane veya gazete ofisine birakın yazısı bulunmaktadır.
} 
Birinci Dünya Savaşı'nda ALA'nın ABD Ordusuna Yönelik Hazırlanan Propaganda Posterleri Üzerine İnceleme An Examination of the ALA's Propaganda Posters for the Us Army During the First World War

\section{Tablo 5}

Hjelmslev'in Modeli Üzerinden Hediye Konulu Propaganda Posterinin Analizi

\begin{tabular}{cc}
\hline Anlatımın Tözü & Bir asker ve kitaplar \\
\hline Anlatımın Biçimi & Askerin sıraya dizilmiş kitapları taşıması \\
İçeriğin Tözü & Kitap ihtiyacı \\
\hline İçeriğin Biçimi & ABD askerlerine kitap yardımının teşvik edilmesi \\
\hline
\end{tabular}

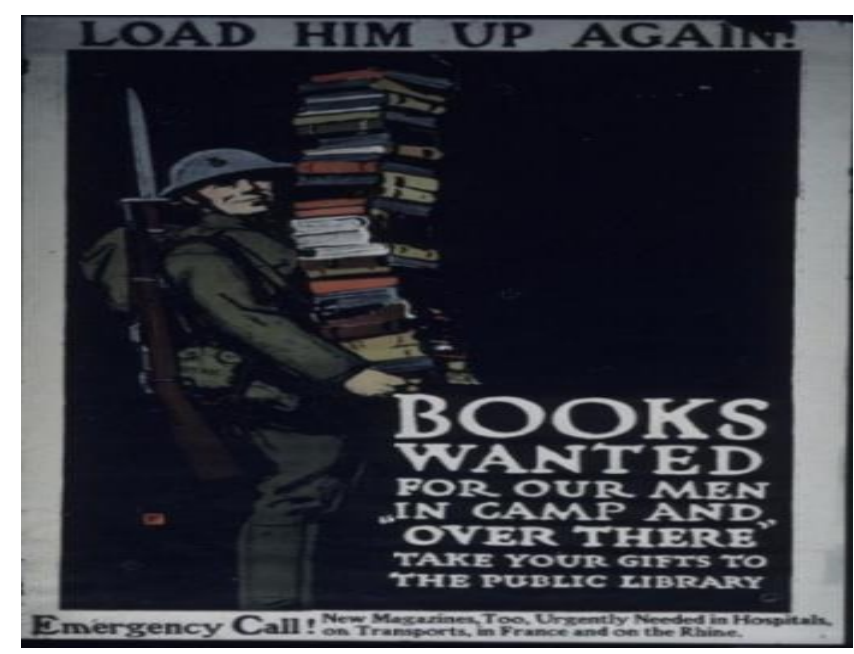

Poster 3. Hediye Konulu Propaganda Posteri ${ }^{3}$ (Hoover Institution, 2021c).

Soyutlama boyutunda kitap yardımı ön plana çıkmaktadır. Posterdeki yazılı kodlardan askerin bulunduğu yerin konumlandırma açısından kamp olduğu aktarılmaktadır. Askerin kitapları taşıması eyleme geçme boyutunu yansıtmaktadır. Askerlerin kitap istemesi çözüm açısını belirtmektedir. Düşünüm boyutunda askerlerin kitaplara ihtiyaç duyması aktarılmaktadır. Koda açısından ABD halkının kitap yardımı yapması gerektiği vurgulanmaktadır. Genel olarak değerlendirildiğinde posterde çalışmada incelenen ilk iki posterin aksine ABD'li askerlerin çok sayıda kitaba ihtiyaç duyduğu algısı meydana getirilmektedir. Posterde askerin fazla sayıda kitabı taşıması, bir askerin çok sayıda kitap okuyabileceği mesajını vermektedir. $\mathrm{Bu}$ şekilde ABD ordusunda kitap ihtiyacının fazla olduğuna yönelik düşünce oluşturularak, ABD halkının kitap yardımının önemine vurgu yapılmaktadır.

\section{Tablo 6}

Labov'un Modeli Üzerinden Hediye Konulu Propaganda Posterinin Analizi

\begin{tabular}{cccccc}
\hline Soyutlama & Konumlandırma & Eyleme Geçme & Çözüm & Düşünüm & Koda \\
Kitap & \multirow{2}{*}{ Kamp } & Askerin & Askerlerin & Askerlerin & ABD halkının kitap \\
yardımı & kitapları & kitap & kitaplara ihtiyaç & yardımı yapması \\
& & taşıması & istemesi & duyması & gerektiği \\
\hline
\end{tabular}

\footnotetext{
${ }^{3}$ Posterde, Tekrar doldurun! Adamlarımı için kampta ve "ta ötede" aranan kitaplar. Hediyelerinizi halk kütüphanesine götürün. Acil çağrr! Hastanelerde, nakliyelerde, Fransa'da ve Ren'de yeni dergilere acilen ihtiyaç duyulmaktadır yazısı bulunmaktadır.
} 


\section{Dolar Konulu Propaganda Posteri}

Dolar konulu propaganda posteri, 1918 yılına tarihlenmektedir. Anlatımın tözü üzerinden ele alındığında posterde asker ve kitap gösterilmektedir. Anlatımın biçimi boyutunda incelendiğinde posterde askerin kitap okuması resmedilmektedir. İçeriğin tözü üzerinden ele alındığında posterde okuma isteği ve kitap yardımı vurgulanmaktadır. İçeriğin biçimi boyutunda incelendiğinde posterde $\mathrm{ABD}$ askerlerinin boş zamanlarında kitap okunması için kitap yardımının teşvik edilmesi mesajı verilmektedir.

\section{Tablo 7}

Hjelmslev'in Modeli Üzerinden Dolar Konulu Propaganda Posterinin Analizi

\begin{tabular}{cc}
\hline Anlatımın Tözü & Asker ve kitap \\
\hline Anlatımın Biçimi & Askerin kitap okuması \\
\hline İçeriğin Tözü & Okuma isteği, kitap yardımı \\
İçeriğin Biçimi & ABD askerlerinin boş zamanlarında kitap okunması için kitap yardımının teşvik edilmesi \\
\hline
\end{tabular}

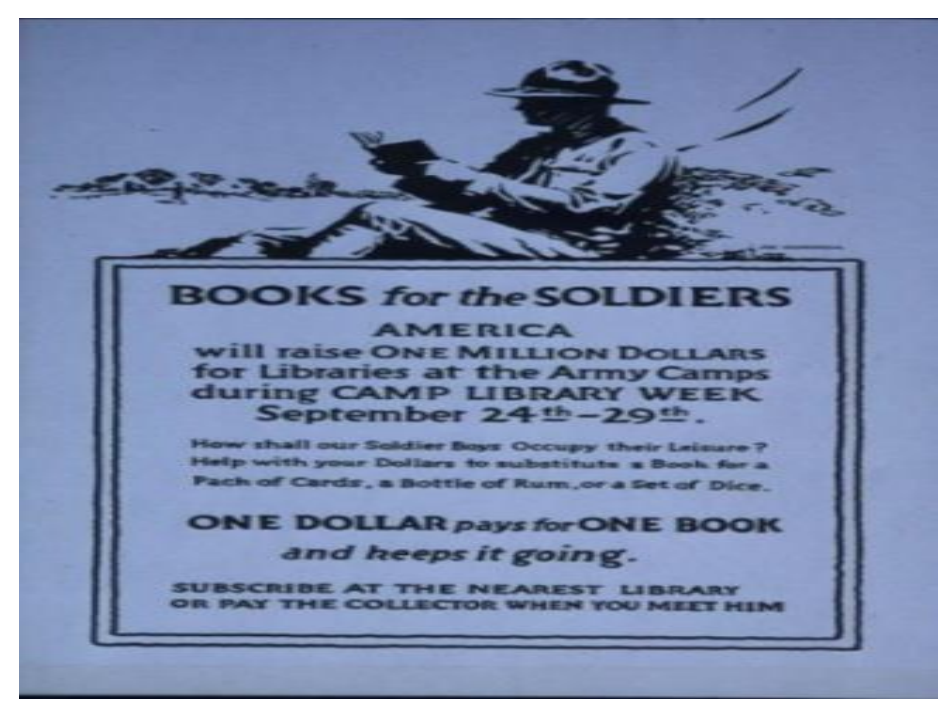

Poster 4. Dolar Konulu Propaganda Posteri ${ }^{4}$ (Hoover Institution, 2021d).

Soyutlama açısından kitap için bağış aktarılmaktadır. Posterdeki yazılı kodlardan askerin bulunduğu yerin konumlandırma açısından kamp olduğu belirtilmektedir. Askerin kitap okuması eyleme geçme açısını yansıtmaktadır. Çözüm boyutunda bağış talebi ön plana çıkarılmaktadır. Askerlerin boş zamanlarında kitap okuması düşünüm açısını aktarmaktadır. Koda boyutunda ABD halkının kitap yardımı yapması gerektiği vurgulanmaktadır. Genel olarak değerlendirildiğinde posterde ABD askerlerinin boş zamanlarını geçirmelerinde kitapların önemli bir rol üstlendiğine vurgu yapılmaktadır. Posterdeki yazılı kodlar üzerinden ABD halkının, ABD askerlerine boş zamanlarında kullanacakları "kart, zar ve rom" yerine kitap göndermesi teşvik edilmektedir.

\footnotetext{
4 Posterde, Askerler için kitaplar. Amerika, 24-29 Eylül Kamp Kütüphanesi Haftası sırasında ordu kamplarındaki kütüphaneler için bir milyon dolar toplayacak. Asker çocuklarımız boş zamanlarını nasıl geçirecek? Bir paket kart, bir şişe rom veya bir dizi zar yerine bir kitap koymak için dolarınla yardım et. Bir kitap için bir dolar ödeniyor ve devam ediyor. En yakın kütüphaneye abone olun veya görüştüğünüzde koleksiyoncuya ödeme yapın yazısı bulunmaktadır
} 
Birinci Dünya Savaşı'nda ALA'nın ABD Ordusuna Yönelik Hazırlanan Propaganda Posterleri Üzerine İnceleme An Examination of the ALA's Propaganda Posters for the Us Army During the First World War

Tablo 8

Labov'un Modeli Üzerinden Dolar Konulu Propaganda Posterinin Analizi

\begin{tabular}{cccccc}
\hline Soyutlama & Konumlandırma & Eyleme Geçme & Çözüm & Düşünüm & Koda \\
$\begin{array}{c}\text { Kitap için } \\
\text { bağış }\end{array}$ & Kamp & $\begin{array}{c}\text { Askerin kitap } \\
\text { okuması }\end{array}$ & Bağış talebi & $\begin{array}{c}\text { Askerlerin boş } \\
\text { zamanlarında kitap } \\
\text { okuması }\end{array}$ & $\begin{array}{c}\text { ABD halkının kitap } \\
\text { yardımı yapması } \\
\text { gerektiği }\end{array}$ \\
\hline
\end{tabular}

\section{Kartal Konulu Propaganda Posteri}

Kartal konulu propaganda posteri, 1917-1918 y1lları arasında tarihlenmektedir. Anlatımın tözü boyutunda incelendiğinde posterde kartal ve kitaplar gösterilmektedir. Anlatımın biçimi üzerinden ele alındığında posterde kartalın kitapları taşıması resmedilmektedir. İçeriğin tözü boyutunda incelendiğinde posterde $\mathrm{ABD}$ halkı ve kitap yardımı ön planı çıkarılmaktadır. İçeriğin biçimi üzerinden ele alındığında posterde ABD halkının ABD ordusuna kitap yardımı mesajı verilmektedir.

Tablo 9

Hjelmslev'in Modeli Üzerinden Kartal Konulu Propaganda Posterinin Analizi

\begin{tabular}{cc}
\hline Anlatımın Tözü & Kartal ve kitaplar \\
\hline Anlatımın Biçimi & Kartalın kitapları taşıması \\
\hline İçeriğin Tözü & ABD halkı, kitap yardımı \\
\hline İçeriğin Biçimi & ABD halkının ABD ordusuna kitap yardımı \\
\hline
\end{tabular}

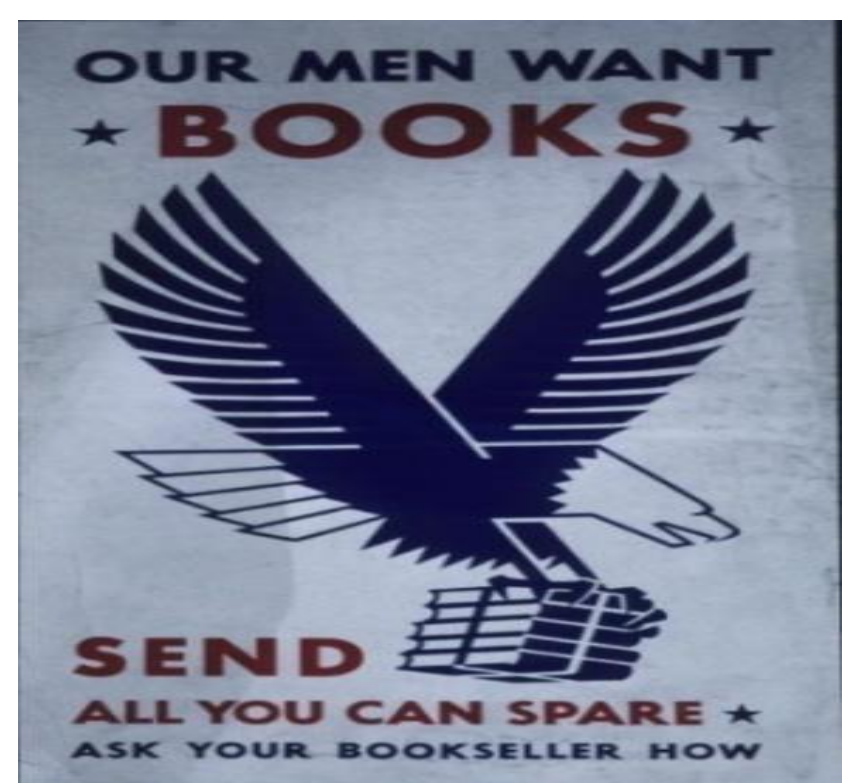

Poster 5. Kartal Konulu Propaganda Posteri ${ }^{5}$ (Hoover Institution, 2021e).

Soyutlama boyutunda kitap yardımı aktarılmaktadır. Posterdeki yazılı koddan konumlandırma açısından kitapçı belirtilmektedir. Kartalın kitapları taşıması eyleme geçme boyutunu yansıtmaktadır. Kitap yardımı için kitapçılarla iletişime geçişmesi çözüm açısını aktarmaktadır. ABD askerlerinin kitaplara ihtiyaç duyması düşünüm boyutunu ifade

\footnotetext{
${ }^{5}$ Posterde, Evlatlarımız kitap istiyor. Verebildiğiniz her şeyi gönderin. Kitapçınıza nasıl olduğunu sorun yazısı
} bulunmaktadır yazısı bulunmaktadır. 
etmektedir. Koda açısından ABD halkının kitap bağışında bulunması vurgulanmaktadır. Genel olarak değerlendirildiğinde posterde metalepsis bir anlatımın kullanıldı̆̆ çıkmaktadır. Posterde ABD’nin simgesi kartal, ABD halkını temsil etmektedir. Kartalın pençelerinde kitapları taşımasıyla $\mathrm{ABD}$ halkının $\mathrm{ABD}$ ordusuna kitap yardımı yapması aktarılmaktadır. Metalepsis anlatımda kartal, güç, hız ve çeviklik metaforları üzerinden yansitılmakta ve bu özellikler de doğrudan ABD halkına addedilmektedir. Posterde ABD'nin simgesi kartalın kullanılmasıyla aynı zamanda ABD askerlerine kitap yardımı yapılmasının ulusal bir sorumluluk olduğuna yönelik algı da meydana gelebilmektedir.

Tablo 10

Labov'un Modeli Üzerinden Kartal Konulu Propaganda Posterinin Analizi

\begin{tabular}{|c|c|c|c|c|c|}
\hline Soyutlama & Konumlandırma & Eyleme Geçme & Çözüm & Düşünüm & Koda \\
\hline $\begin{array}{c}\text { Kitap } \\
\text { yardımı }\end{array}$ & Kitapçı & $\begin{array}{l}\text { Kartalın kitapları } \\
\text { taşıması }\end{array}$ & $\begin{array}{l}\text { Kitap yardımı } \\
\text { için kitapçılarla } \\
\text { iletişime geçme }\end{array}$ & $\begin{array}{c}\text { ABD askerlerinin } \\
\text { kitaplara ihtiyaç } \\
\text { duyması }\end{array}$ & $\begin{array}{c}\text { ABD halkının } \\
\text { kitap bağışında } \\
\text { bulunması }\end{array}$ \\
\hline
\end{tabular}

\section{Kitap Okumayı Teşvik Eden Propaganda Posterleri}

Çalışmanın bu kısmında kitap okumayı teşvik eden arkadaş, karakter, bilgi, cephe ve kamp konulu posterler incelenmiştir.

\section{Arkadaş Konulu Propaganda Posteri}

Arkadaş konulu propaganda posteri, 1914-1918 yılları arasında tarihlenmektedir. Anlatımın tözü üzerinden ele alındığında posterde askerler, kitaplar ve kitaplık resmedilmektedir. Anlatımın biçimi boyutunda incelendiğinde posterde bir askerin kitap okuması, bir askerin kitaplıktan kitap seçmesi gösterilmektedir. İçeriğin tözü üzerinden ele alındığında posterde kitap okuma isteği vurgulanmaktadır. İçeriğin biçimi boyutunda incelendiğinde posterde ABD askerlerinin boş zamanlarını kitap okuyarak geçirmesinin teşvik edilmesi ön plana çıkarılmaktadır.

Tablo 11

Hjelmslev'in Modeli Üzerinden Arkadaş Konulu Propaganda Posterinin Analizi

\begin{tabular}{cc}
\hline Anlatımın Tözü & Askerler, kitaplık ve kitaplar \\
\hline Anlatımın Biçimi & Bir askerin kitap okuması, bir askerin kitaplıktan kitap seçmesi \\
\hline İçeriğin Tözü & Kitap okuma isteği \\
\hline İçeriğin Biçimi & ABD askerlerinin boş zamanlarını kitap okuyarak geçirmesinin teşvik edilmesi \\
\hline
\end{tabular}




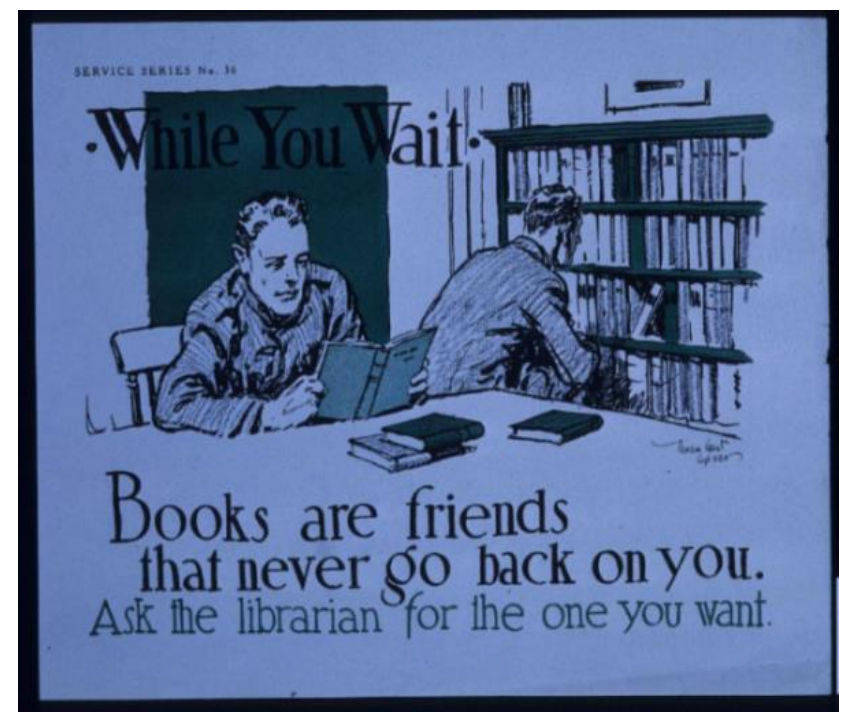

Poster 6. Arkadaş Konulu Propaganda Posteri ${ }^{6}$ (Hoover Institution, 2021f).

Soyutlama açısından kitap okunması aktarılmaktadır. Konumlandırma boyutunda görsel kodlardan askerlerin kütüphanede olduğu anlaşılmaktadır. Askerlerin kitap okuması eyleme geçme açısını yansıtmaktadır. Posterdeki yazılı kodlardan askerlerin kütüphaneciden kitap istemesi çözüm boyutunu belirtmektedir. Askerlerin boş zamanlarında kitap okuması düşünüm açısını aktarmaktadır. Koda boyutunda askerlerin kitap okumasının teşvik edilmesi ön plana çıkarılmaktadır. Genel olarak değerlendirildiğinde posterde ABD askerlerinin boş zamanlarını kitap okuyarak değerlendirmeleri gerektiği mesajı verilmektedir. Posterdeki yazılı kodlarda, kitapların askerlerin arkadaşı olarak tanıtılmasıyla ABD askerlerinin kitap okumasının teşvik edildiği ortaya çıkmaktadır.

Tablo 12

Labov'un Modeli Üzerinden Kartal Konulu Propaganda Posterinin Analizi

\begin{tabular}{|c|c|c|c|c|c|}
\hline Soyutlama & Konumlandırma & Eyleme Geçme & Çözüm & Düşünüm & Koda \\
\hline $\begin{array}{c}\text { Kitap } \\
\text { okunmas1 }\end{array}$ & Kütüphane & $\begin{array}{c}\text { Askerin kitap } \\
\text { okuması }\end{array}$ & $\begin{array}{l}\text { Askerlerin } \\
\text { kütüphaneci } \\
\text { den kitap } \\
\text { istemesi }\end{array}$ & $\begin{array}{l}\text { Askerlerin boş } \\
\text { zamanlarında } \\
\text { kitap okuması }\end{array}$ & $\begin{array}{c}\text { Askerlerin kitap } \\
\text { okumasının teşvik } \\
\text { edilmesi }\end{array}$ \\
\hline
\end{tabular}

\section{Karakter Konulu Propaganda Posteri}

Karakter konulu propaganda posteri, 1917-1918 yılları arasında tarihlenmektedir. Anlatımın tözü boyutunda incelendiğinde posterde Abraham Lincoln'un resmi ve büyük puntolu yazılar bulunmaktadır. Anlatımın biçimi üzerinden ele alındığında posterde büyük puntolu yazılar, Lincoln’un resminin altında gösterilmektedir. İçeriğin tözü boyutunda incelendiğinde posterde model alma ve kişilik kültü vurgulanmaktadır. İçeriğin biçimi üzerinden ele alındığında posterde $\mathrm{ABD}$ askerlerinin kitap okuyarak Lincoln gibi olacağı düşüncesi ön plana çıkarılmaktadır.

\footnotetext{
${ }^{6}$ Posterde, Sen beklerken. Kitaplar asla senden vazgeçmeyen arkadaşlardır. Kütüphaneciden istediğinizi isteyin yazısı bulunmaktadır.
} 
Tablo 13

Hjelmslev’in Modeli Üzerinden Karakter Konulu Propaganda Posterinin Analizi

\begin{tabular}{cc}
\hline Anlatımın Tözü & Abraham Lincoln'un resmi ve büyük puntolu yazılar \\
\hline Anlatımın Biçimi & Büyük puntolu yazıların Lincoln'un resmin altında olması \\
\hline İçeriğin Tözü & Model alma, kişilik kültü \\
\hline
\end{tabular}

\section{İçeriğin Biçimi $\quad \mathrm{ABD}$ askerlerinin kitap okuyarak Lincoln gibi olacağı düşüncesi}

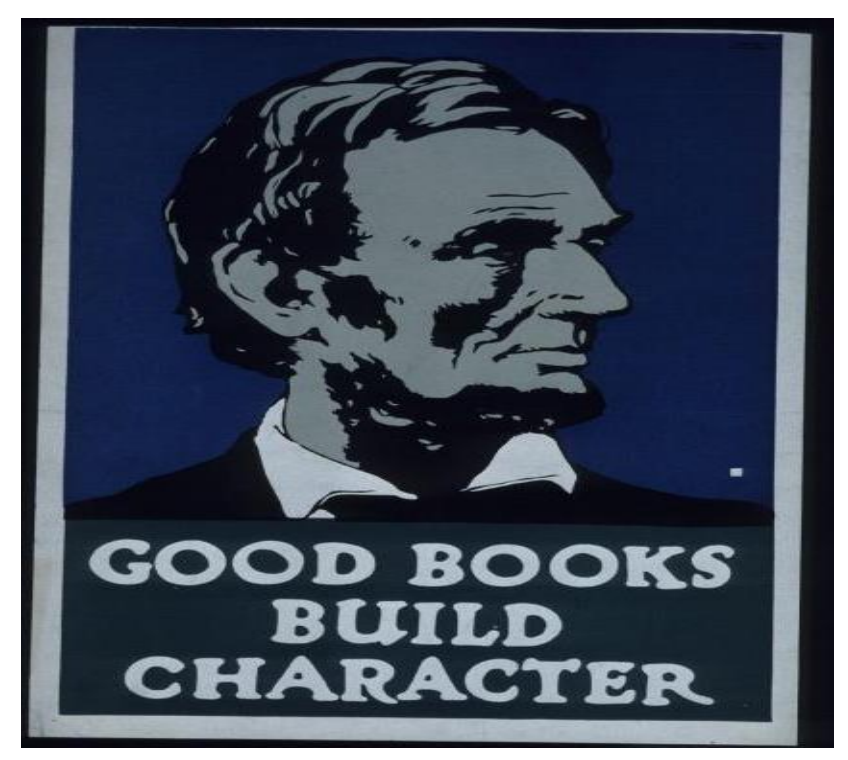

Poster 7. Karakter Konulu Propaganda Posteri ${ }^{7}$ (Hoover Institution, 2021g).

Soyutlama boyutunda kitap okunması aktarılmaktadır. Konumlandırma açısından tarihe vurgu yapılmaktadır. Lincoln'ün resminin ön plana çıkarılması eyleme geçme boyutunu yansıtmaktadır. Çözüm açısından Lincoln'ün örnek alınması aktarılmaktadır. Düşünüm boyutunda kitap okuyarak iyi bir karaktere sahip olunacağı belirtilmektedir. Koda açısından ABD askerlerinin Lincoln gibi olabilmesi için kitap okuması gerektiği yansıtılmaktadır. Genel olarak değerlendirildiğinde posterde 16. ABD başkanı Abraham Lincoln ile kitap okuma arasında bir ilişki kurulmaya çalışılmaktadır. Bu aşamada Lincoln'ün kişilik kültü ön plana çıkarılmaktadır. Lincoln, ABD’nin Amerikan İç Savaşı'nda üstün gelmesindeki ve ABD’de köleliğin kaldırılmasındaki rolünden dolayı ABD tarihinin önde gelen liderlerinden biri olma özelliğini taşımaktadır. Posterin altındaki "İyi kitaplar karakter inşa eder" yazısıyla Lincoln’e atıfta bulunulmakta ve kitap okuyan insanların Lincoln gibi bir karaktere sahip olacağına yönelik mit inşa edilmektedir. İnşa edilen mit üzerinden ABD'de Lincoln'e sevgi duyan kişilerde kitap okuma isteğinin oluşmasına çalışılmaktadır.

\footnotetext{
${ }^{7}$ Posterde, Iyi kitaplar karakter inşa eder yazısına yer vermektedir.
} 
Birinci Dünya Savaşı'nda ALA'nın ABD Ordusuna Yönelik Hazırlanan Propaganda Posterleri Üzerine İnceleme An Examination of the ALA's Propaganda Posters for the Us Army During the First World War

\section{Tablo 14}

Labov'un Modeli Üzerinden Karakter Konulu Propaganda Posterinin Analizi

\begin{tabular}{|c|c|c|c|c|c|}
\hline Soyutlama & Konumlandırma & Eyleme Geçme & Çözüm & Düşünüm & Koda \\
\hline $\begin{array}{c}\text { Kitap } \\
\text { okunması }\end{array}$ & Tarih & $\begin{array}{l}\text { Lincoln’ün } \\
\text { resminin ön plana } \\
\text { çıkarılması }\end{array}$ & $\begin{array}{c}\text { Lincoln’ün } \\
\text { örnek } \\
\text { alınması }\end{array}$ & $\begin{array}{c}\text { İyi bir karakter } \\
\text { için kitap } \\
\text { okunması }\end{array}$ & $\begin{array}{l}\text { ABD askerlerinin } \\
\text { Lincoln gibi } \\
\text { olabilmesi için kitap } \\
\text { okuması gerektiği }\end{array}$ \\
\hline
\end{tabular}

\section{Bilgi Konulu Propaganda Posteri}

Bilgi konulu propaganda posteri, 1917-1918 yılları arasında tarihlenmektedir. Anlatımın tözü üzerinden ele alındığında posterde asker, kitaplar ve binalar resmedilmektedir. Anlatımın biçimi boyutunda incelendiğinde posterde askerin binalara kitaplardan yapılan yolun önünde durması gösterilmektedir. İçeriğin tözü üzerinden ele alındığında posterde kazanım ve gelişim vurgusu yapılmaktadır. İçeriğin biçimi boyutunda incelendiğinde posterde askerlerin kitap okuyarak kendilerini geliştireceği düşüncesi ön plana çıkarılmaktadır.

\section{Tablo 15}

Hjelmslev'in Modeli Üzerinden Bilgi Konulu Propaganda Posterinin Analizi

\begin{tabular}{cc}
\hline Anlatımın Tözü & Asker, kitaplar, binalar \\
\hline Anlatımın Biçimi & Askerin, binalara kitaplardan yapılan yolun önünde durması \\
\hline İçeriğin Tözü & Kazanım, Gelişism \\
\hline İçeriğin Biçimi & Askerlerin kitap okuyarak kendilerini geliştireceği düşüncesi \\
\hline
\end{tabular}

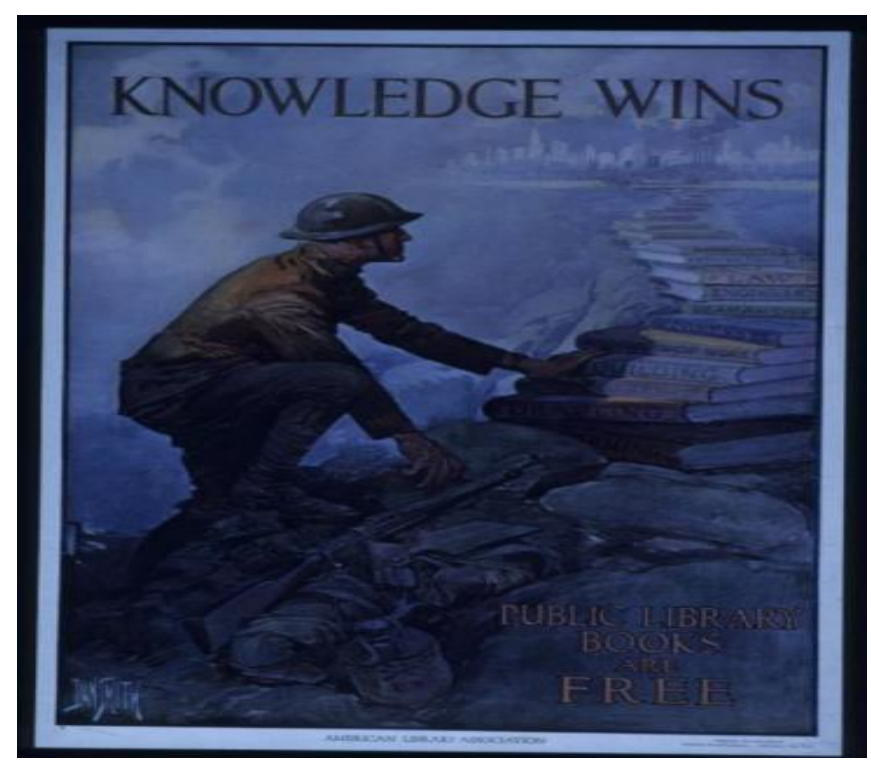

Poster 8. Bilgi Konulu Propaganda Posteri ${ }^{8}$ (Hoover Institution, 2021h).

Soyutlama açısından kitap okunması aktarılmaktadır. Konumlandırma boyutunda şehir ön plana çıkarılmaktadır. Askerin kitaplardan yapılan yolun önünde durması eyleme geçme açısını yansıtmaktadır. Posterdeki yazılı kodlardan askerlerin kütüphaneden kitap alması çözüm boyutunu aktarmaktadır. Düşünüm açısından kitap okuyarak bilgili olunacağı mesajı

\footnotetext{
${ }^{8}$ Posterde, Bilgi kazanır. Halk kütüphanesi kitapları ücretsizdir yazısı bulunmaktadır.
} 
verilmektedir. Koda boyutunda ABD askerlerinin kendilerini geliştirmesi için kitap okuması gerektiği belirtilmektedir. Genel olarak değerlendirildiğinde posterde kitap okuma ve kişisel gelişim arasında bir ilişki kurulduğuna yönelik algı meydana gelmektedir. Posterdeki görsel kodlarda ABD askerlerinin evlerine gidecekleri zamana kadar boş zamanlarını kitap okuyarak geçirmeleri teşvik edilmektedir. Askerlerin bu şekilde zamanlarını verimli kullanacaklarına yönelik düşünce oluşmaktadır.

\section{Tablo 16}

Labov'un Modeli Üzerinden Bilgi Konulu Propaganda Posterinin Analizi

\begin{tabular}{|c|c|c|c|c|c|}
\hline Soyutlama & Konumlandırma & Eyleme Geçme & Çözüm & Düşünüm & Koda \\
\hline $\begin{array}{c}\text { Kitap } \\
\text { okunması }\end{array}$ & Şehir & $\begin{array}{c}\text { Askerin } \\
\text { kitaplardan } \\
\text { yapılan yolun } \\
\text { önünde durması }\end{array}$ & $\begin{array}{c}\text { Askerlerin } \\
\text { kütüphaneden } \\
\text { kitap alması }\end{array}$ & $\begin{array}{c}\text { Kitap okuyarak } \\
\text { bilgili } \\
\text { olunacağ } 1\end{array}$ & $\begin{array}{c}\text { ABD askerlerinin } \\
\text { kendilerini } \\
\text { geliştirmesi için kitap } \\
\text { okuması gerektiği }\end{array}$ \\
\hline
\end{tabular}

\section{Cephe Konulu Propaganda Posteri}

Cephe konulu propaganda posteri, 1917-1918 yılları arasında tarihlenmektedir. Anlatımın tözü boyutunda incelendiğinde posterde askerler, kitaplar ve sığınak gösterilmektedir. Anlatımın biçimi üzerinden ele alındığında posterde sığınağın içerisinde askerlerin kitap okuması resmedilmektedir. İçeriğin tözü boyutunda incelendiğinde posterde okuma isteği mesajı verilmektedir. İçeriğin biçimi üzerinden ele alındığında posterde ABD askerlerinin zor şartlarda bile kitap okuduğu ön plana çıkarılmaktadır.

\section{Tablo 17}

Hjelmslev'in Modeli Üzerinden Cephe Konulu Propaganda Posterinin Analizi

\begin{tabular}{cc}
\hline Anlatımın Tözü & Askerler, kitaplar, sığınak \\
\hline Anlatımın Biçimi & Sığınağın içerisinde askerlerin kitap okuması \\
İçeriğin Tözü & Okuma isteği \\
İçeriğin Biçimi & ABD askerlerinin zor şartlarda bile kitap okuduğu \\
\hline
\end{tabular}

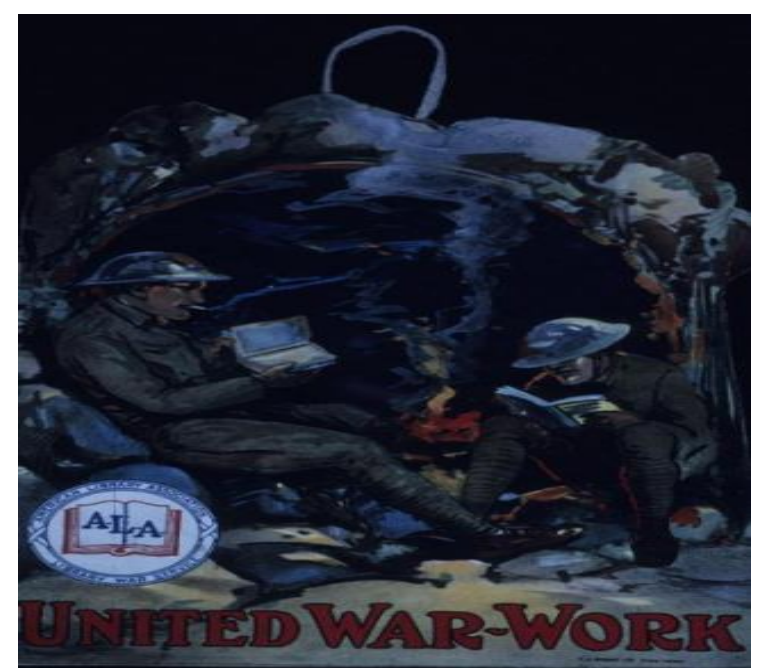

Poster 9. Cephe Konulu Propaganda Posteri ${ }^{9}$ (Hoover Institution, 2021i).

\footnotetext{
${ }^{9}$ Posterde, Birleşik Savaş-Çalışma yazısı bulunmaktadır.
} 
Soyutlama boyutunda kitap okuma aktarılmaktadır. Konumlandırma açısından askerlerin siper ya da sığınakta olduğuna yönelik algı meydana getirilmektedir. Askerlerin kitap okuması eyleme geçme boyutunu yansıtmaktadır. Kitap okumanın önemli bir boş zaman aktivitesi olduğu çözüm açısını belirtmektedir. Düşünüm boyutunda askerlerin boş zamanlarında kitap okuduğu aktarılmaktadır. Koda açısından askerlerin boş zamanlarında kitap okuması teşvik edilmektedir. Genel olarak değerlendirildiğinde posterde iki askerin siperde ya da sığınakta kitap okumasıyla ABD askerlerinin cephede bile boş zamanlarında kitap okuduğuna yönelik mit inşa edilmektedir. İnşa edilen mitle kitapların ABD askerleri için önemli bir yer tuttuğuna yönelik algı meydana gelmektedir. Bu şekilde poster üzerinden ABD askerlerinin zor şartlarda bile boş zamanlarında kitap okuması teşvik edilmektedir.

\section{Tablo 18}

Labov'un Modeli Üzerinden Cephe Konulu Propaganda Posterinin Analizi

\begin{tabular}{llllll}
\hline Soyutlama & Konumlandırma & Eyleme Geçme & Çözüm & Düşünüm & Koda \\
Kitap & Siper/Sığınak & Askerlerin kitap & Kitap & Askerlerin boş & Askerlerin boş \\
okuma & & okuması & okumanın & zamanlarında & zamanlarında kitap \\
& & & önemli bir & kitap okuduğu & okumasının teşvik \\
& & & boş zaman & & edilmesi \\
& & & aktivitesi & & \\
& & & olduğu & \\
\hline
\end{tabular}

\section{Kamp Konulu Propaganda Posteri}

Kamp konulu propaganda posteri, 1917-1918 yılları arasında tarihlenmektedir. Anlatımın tözü üzerinden ele alındığında posterde asker ve kitaplar resmedilmektedir. Anlatımın biçimi boyutunda incelendiğinde posterde askerin kitap okuması gösterilmektedir. İçeriğin tözü üzerinden ele alındığında posterde kitap okuma isteği mesajı verilmektedir. İçeriğin biçimi boyutunda incelendiğinde posterde ABD askerlerinde kitap okuma isteğinin oluşturulmaya çalışılması vurgulanmaktadır.

\section{Tablo 19}

Hjelmslev'in Modeli Üzerinden Kamp Konulu Propaganda Posterinin Analizi

\begin{tabular}{lc}
\hline Anlatımın Tözü & Asker ve kitaplar \\
\hline Anlatımın Biçimi & Askerin kitap okuması \\
\hline Icçeriğin Tözü & Kitap okuma isteği \\
\hline İçeriğin Biçimi & ABD askerlerinde kitap okuma isteğinin oluşturulmaya çalışılması \\
\hline
\end{tabular}




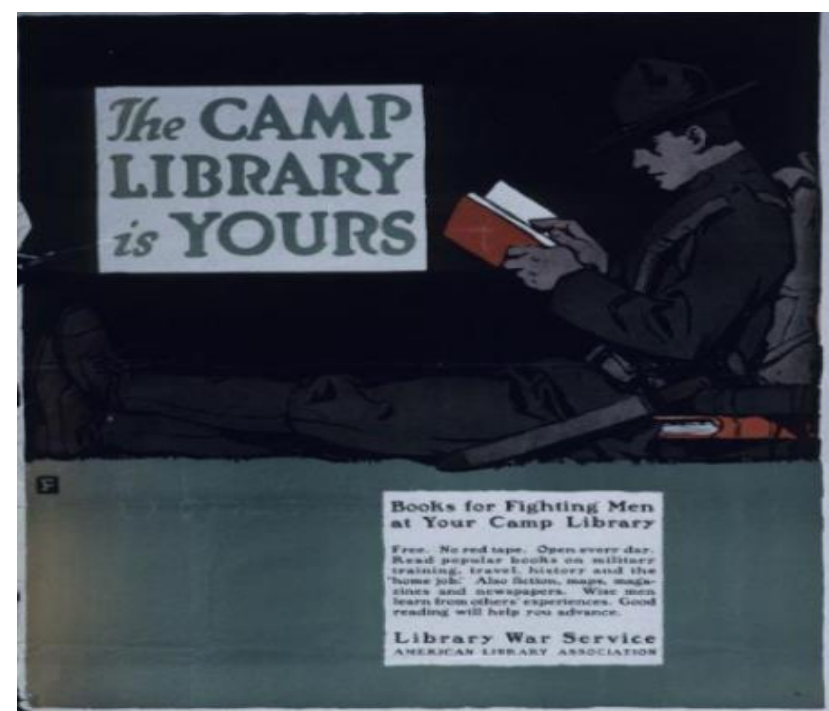

Poster 10. Kamp Konulu Propaganda Posteri ${ }^{10}$ (Hoover Institution, 2021j).

Soyutlama açısından kitap okuma aktarılmaktadır. Posterdeki yazılı kodlardan konumlandırma boyutunda kampa vurgu yapılmaktadır. Askerin kitap okuması eyleme geçme açısını aktarmaktadır. Kitap okumanın bireyi geliştireceği çözüm boyutunu yansıtmaktadır. Düşünüm açısından askerlerin boş zamanlarında kitap okumasına vurgu yapılmaktadır. Koda boyutunda ABD askerlerinin deneyim kazanması için kitap okuması gerektiği belirtilmektedir. Genel olarak değerlendirildiğinde posterdeki yazılı kodlardan kütüphanelerin ABD askerlerine okunacak geniş bir yelpaze sunduğu vurgulanmakta, aynı zamanda ABD askerlerinin kitap okuyarak başkalarının deneyimlerinden yararlanabileceği ve kendilerini geliştirebileceği aktarılmaktadır. Posterde yer alan asker görseli de idealize edilen kitap okuyan ABD askerini yansıtmaktadır. Bu şekilde ABD askerlerinde kitap okumaya yönelik ilgi uyandırılmaya çalışılmaktadır.

\section{Tablo 20}

Labov'un Modeli Üzerinden Kamp Konulu Propaganda Posterinin Analizi

\begin{tabular}{|c|c|c|c|c|c|}
\hline Soyutlama & Konumlandırma & Eyleme Geçme & Çözüm & Düşünüm & Koda \\
\hline $\begin{array}{l}\text { Kitap } \\
\text { okuma }\end{array}$ & Kamp & $\begin{array}{c}\text { Askerin kitap } \\
\text { okuması }\end{array}$ & $\begin{array}{c}\text { Kitap } \\
\text { okumanın } \\
\text { bireyi } \\
\text { geliştireceği }\end{array}$ & $\begin{array}{l}\text { Askerlerin boş } \\
\text { zamanlarında } \\
\text { kitap okuduğu }\end{array}$ & $\begin{array}{c}\text { ABD askerlerinin } \\
\text { deneyim kazanması } \\
\text { için kitap okuması } \\
\text { gerektiği }\end{array}$ \\
\hline
\end{tabular}

\section{Sonuç}

Çalışma kapsamında incelenen propaganda posterlerinde genel olarak ALA'nın hem ABD halkının kitap yardımında bulunmasında hem de ABD askerlerinin kitap okumasının teşvik edilmesinde ABD askerlerinin temsillerini kullandığı ortaya çıkarılmıştır. Propaganda posterlerinde $\mathrm{ABD}$ askerleri kitap okurken sunularak, $\mathrm{ABD}$ halkının $\mathrm{ABD}$ askerlerine kitap yardımında bulunması istenmektedir. $\mathrm{Bu}$ aşamada propaganda posterlerinde ABD halkı tarafından yapılacak kitap yardımlarının ABD askerleri tarafından verimli bir şekilde

\footnotetext{
${ }^{10}$ Posterde, Kamp kütüphanesi sizindir. Kamp kütüphanenizde savaşan erkekler için kitaplar. Bedava. Bürokrasi yok. Her gün açık. Askeri eğitim, seyahat, tarih ve 'ev işi' ile ilgili popüler kitapları okuyun. Ayrıca kurgu, haritalar, dergiler ve gazeteler. Bilge adamlar başkalarının deneyimlerinden öğrenirler. Faydalı okumak ilerlemenize yardımcı olacaktır. Kütüphane Savaş Servisi. Amerikan Kütüphane Derneği yazısı bulunmaktadır.
} 
kullanılacağına yönelik algı oluşturulmaktadır. Bağışta bulunulan kitapların ABD askerleri tarafından okunacağına ve bağışların ABD ordusu için önemli bir hizmet olacağına yönelik ABD halkının ikna edilmesine çalışılmaktadır. Kitap yardımını konu alan propaganda posterlerinde $\mathrm{ABD}$ askerleri ön plana çıkarılarak, kitap yardımını talep edenin ALA değil doğrudan $\mathrm{ABD}$ askerleri olduğuna yönelik algı oluşturulmaktadır. Diğer yandan propaganda posterlerinde kitap bağışı konusunda $\mathrm{ABD}$ halkı seferber edilerek, $\mathrm{ABD}$ askerlerine yapılacak kitap bağışlarının ulusal bir sorumluluk gibi algılanılmasına da çalışıldığı ileri sürülebilmektedir.

ALA'nın propaganda posterlerinde boş zamanlarında kitap okuyan ABD askerlerinin idealize edildiği ve bu şekilde ordudaki tüm $\mathrm{ABD}$ askerlerinin boş zamanlarında kitap okumasının teşvik edilmeye çalışıldığı ortaya konulmaktadır. Propaganda posterleri üzerinden kitap okumanın $\mathrm{ABD}$ askerleri üzerindeki kazanımlarına vurgu yapılarak $\mathrm{ABD}$ askerleri kitap okuma konusunda motive edilmeye çalışılmaktadır. Bu aşamada propaganda posterlerindeki görsel ve yazılı göstergeler üzerinden $\mathrm{ABD}$ askerlerinin boş zaman aktivitelerinde kitap okumayı öncelikli hale getirmesine çalışıldığı belirtilebilmektedir. ALA'nın propaganda posterlerinde kitap okumanın, ABD askerlerinin boş zamanlarının bir alışkanlığı haline getirilmesinin hedeflendiği söylenebilmektedir. $\mathrm{Bu}$ süreçte propaganda posterlerinde $\mathrm{ABD}$ askerleri kışlada, karargâhta, kampta vb. kitap okurken temsil edilmektedir.

ALA'nın propaganda posterleri üzerinden bilginin öneminin hem ABD halkına hem de ABD ordusuna yansıtmaya çalıştı̆̆ sonucuna ulaşılmıştır. Posterlerdeki incelemeler sonucunda ALA'nın Birinci Dünya Savaşı'nın zor şartları altında ABD askerlerinin kitaplar üzerinden bilgiye erişimini sağlamak için çalıştı̆ı ortaya çıkmıştır. Savaş zamanında bile askerlerin bilgiye erişimini mümkün kılmak amacıyla $\mathrm{ABD}$ halkını posterler üzerinden kitap bağı̧̧1 konusunda seferber etmeye çalışmıştır. Çalışmadaki bulgular genel olarak değerlendirildiğinde Birinci Dünya Savaşı'nda ALA tarafından kullanılan propaganda posterlerinin $\mathrm{ABD}$ halkının kitap bağışında bulunmasında ve $\mathrm{ABD}$ askerlerinin kitap okuma alışkanlığı kazanmasında önemli bir rol üstlendiği ileri sürülebilmektedir. Nitekim propaganda posterlerinde $\mathrm{ABD}$ halkının kitap bağışı sürecinde "Neden bağışta bulunmalıyım?" ve "Kitap bağı̧̧ı ne kadar verimli kullanılacak?" gibi sorularına cevap bulması sağlanabilmektedir. Benzer şekilde propaganda posterleri üzerinden $\mathrm{ABD}$ askerlerinin kitap okuma alışkanlığı kazandırılmasında "Neden kitap okumalıyım?" sorusuna yanıt bulmasına da yardımcı olabilmektedir. Çalışmada elde edilen bulgular, ALA'nın Birinci Dünya Savaşı'nda $\mathrm{ABD}$ ordusu özelindeki faaliyetlerine ş̧ık tutması bakımından önem taşımaktadır. ABD'de de İkinci Dünya Savaşı'nda da Birinci Dünya Savaşı'na benzer şekilde kitap bağışıı konu alan posterler kullanılmıştır. Diğer yandan Birinci Dünya Savaşı'nda İtilaf Devletleri içerisinde yer alan ABD'de olduğu gibi İttifak Devletleri'nden Almanya'da da askerlerin kitap bağışını ve kitap okumasını teşvik eden propaganda posterleri hazırlanmıştır. Gelecek çalışmaların bu posterler üzerinden incelemede bulunmasıyla savaş sırasında askerlere yönelik kitap bağışına ve askerlerin kitap okumasının teşvik edilmesine yönelik kampanyalarla ilgili literatüre katkı sağlanacağı düşünülmektedir. Ayrıca gelecek çalışmaların ALA'nın günümüzde sosyal medya üzerinden gerçekleştirdiği paylaşımları ele alması önerilmektedir. Böylece geçmişten günümüze farklı kitle iletişim araçları üzerinden ALA'nın faaliyetlerindeki değişimin ortaya konulması söz konusu olabilir. 
Çalışma sonucunda posterlerin kitap bağışı sağlama ve kitap okumayı teşvik etmede ne şekilde kullanılabileceğine yönelik belirli fikirler ortaya çıkmıştır. Bu aşamada kitap bağışı amacıyla hazırlanacak posterlerde kitap bağışı yapılacak kişilerin kitap okumaya ne kadar istekli olduğunun vurgulanmasının kitap bağışı konusunda önem taşıdığı ileri sürülebilmektedir. Diğer yandan kitap okumanın teşvik edilmesi amacıyla hazırlanacak posterlerde de doğrudan kitapların insan hayatındaki öneminin vurgulanmasının hedef kitle üzerinde olumlu etkisinin olabileceği belirtilebilmektedir.

\section{Kaynakça}

ALA Committees. (2021). http://www.ala.org/aboutala/committees

ALA Governance. (2021). http://www.ala.org/aboutala/

ALA History. (2021). http://www.ala.org/aboutala/node/230/

ALA Mission. (2021). http://www.ala.org/aboutala/missionpriorities

Aladağ, H. (2019). 1960'lar sonrası kütüphanecilik tarihimiz içinde bazı "Kütüphane Haftası" afişlerinin Roland Barthes'in göstergebilim metodu çerçevesinde analizi. Uluslararası Sosyal ve Ĕgitim Bilimleri Dergisi, 6(12), 133-147.

ALIP. (2021). The American Library in Paris. https://americanlibraryinparis.org/history/

American Library Association Archives. (2021). World War I Library War Service. https://archives.library.illinois.edu/ala/search-holdings/guides/world-war-i-library-war-service/

Andresen, M. (2010). Books for the doughboys. https://www.army.mil/article/36859/books_for_the_doughboys

Avcı, Ö. ve Çakı, C. (2020). Milan Nedić iktidarında Sırp toplumunda düşman inşası propagandasına yönelik bir inceleme. Uluslararası Suçlar ve Tarih, (21), 81-110.

Baytimur, T., Çakı, C., Arıca, F. (2020). The propaganda in Armenia of the five-year development plans implemented in the Soviet Union. Review of Armenian Studies, (42), 81-102.

Bertram, C. S. (2021). The American Library Association and the American Library in Paris: A 100 year legacy and connection in the archives. IdeAs. Idées d'Amériques, (17), 1-6. doi: 10.4000/ideas. 11121

Brichford, M. (1991). The Context for a history of the American Library Association. Libraries \& Culture, 26(2), 348-356.

Collins, R. F. (2015). Myth as propaganda in World War I: American volunteers, Victor Chapman, and French journalism. Journalism \& Mass Communication Quarterly, 92(3), 642-661. doi: $10.1177 / 1077699015573006$

Coolidge, K. K. (2005). Baseless hysteria: The controversy between the department of justice and the American Library Association over the USA PATRIOT Act. Law Library Journal, 97(1), 7-30.

Çakı, C., Zorlu, Y. ve Karaca, M. (2017). Türk sinemasında Nazizm ideolojisi: "Kırımlı" filmi ve göstergebilimsel analizi. Sosyoloji Konferansları, (56), 67-95. doi: 10.18368/iusoskon.328523

Çakı, C., Gazi, M. A., Çakı, G. ve Gülada, M. O. (2020). Likbez kampanyası dönemindeki propaganda posterleri üzerine göstergebilimsel bir inceleme. Türk Kütüphaneciliği, 34(4), 663-692. doi: $10.24146 / \mathrm{tk} .806892$

Demm, E. (1993). Propaganda and caricature in the First World War. Journal of Contemporary History, 28(1), 163-192. doi: 10.1177/002200949302800109 
Dündar, G. (2020). Emek sömürüsü bağlamında insan ticareti. Göç Araştırmaları Dergisi, 6(2), 326349.

Fischer, N. (2016). The Committee on Public Information and the birth of US state propaganda. Australasian Journal of American Studies, 35(1), 51-78.

Fiske, J. (2017). İletişim çalışmalarına giriş. (5. bs.). Bilim ve Sanat Yayınları.

Fulwider, C. R. (2017). German propaganda and US neutrality in World War I. The United States: University of Missouri Press.

Gazi, M. A., Çakı, C., Gülada, M. O. ve Çakı, G. (2020). Çin Halk Cumhuriyeti kültür devrimi sürecinde okuma alışkanlığının propaganda posterlerinde sunumu. Türk Kütüphaneciliği, 34(3), 406-431. doi: 10.24146/tk.778685

Gazi, M. A., Çakı, C, Karaca, M ve Çakı, G. (2021). 1980 Nikaragua okuryazarlık kampanyası'ndaki propaganda posterlerinin kitap okuma boyutunda incelenmesi. Türk Kütüphaneciliği, 35(1), 6488. doi: $10.24146 / \mathrm{tk} .873618$

Gullace, N. F. (1997). Sexual violence and family honor: British propaganda and international law during the First World War. The American Historical Review, 102(3), 714-747. doi: $10.2307 / 2171507$

Gülada, M. O. (2019). 1936 Berlin Olimpiyatları'nda spor yayıncılığının propaganda amaçlı kullanımı: Olympia filmi üzerine inceleme. TRT Akademi, 4(8), 326-344.

Hart, B. L. (2018). Birinci Dünya Savaşı tarihi. (K. Bağrıaçık, Çev.). (3. bs.). Türkiye İş Bankası Yayınları.

Heim, K. M. (1991). Adult services within the American Library Association: A historical examination of the move to synthesis. $R Q, 30(3), 386-394$.

Hoover Institution. (2021a). Para konulu propaganda posteri. https://digitalcollections.hoover.org/objects/40344/span-classqueryhlheyspan-spanclassqueryhlfel?ctx=f208e33a3a5aeaf8602a701ead9d0b2b2caf5bba\&idx =1

Hoover Institution. (2021b). Zihin konulu propaganda posteri. https://digitalcollections.hoover.org/objects/40951/fortify-the-mind-camp-library-weekseptember-2430-leave?ctx=851e102ca25b8f80242d388d8110af4ca376c4b1\&idx $=47$

Hoover Institution. (2021c). Hediye konulu propaganda posteri. https://digitalcollections.hoover.org/objects/41044/load-him-up-again-books-wanted-for-ourmen-in-camp-and-ove?ctx=6ca54637f96c5f5eab2578b4f935c6965b98266c \&idx=81

Hoover Institution. (2021d). Dolar konulu propaganda posteri. https://digitalcollections.hoover.org/objects/40883/books-for-the-soldiers--help-with-yourdollars-to-substit?ctx=36ae9c046deb3d0a5366b81dceb1c8b35131cc0a\&idx=22

Hoover Institution. (2021e). Kartal konulu propaganda posteri. https://digitalcollections.hoover.org/objects/40768/our-men-want-books-send-all-you-can-spareask-your-booksel?ctx $=44 \mathrm{f} 641 \mathrm{~b} 73948$ bdadb415e18a5767e72da43be399\&idx $=29$

Hoover Institution. (2021f). Arkadaş konulu propaganda posteri https://digitalcollections.hoover.org/objects/37666/while-you-wait-books-are-friends-that-nevergo-back-on-you?ctx=09bbfed02c4c6ae5e3cbb08be16bc337e420890e\&idx=97

Hoover Institution. (2021g). Karakter konulu propaganda posteri. https://digitalcollections.hoover.org/objects/40870/good-books-buildcharacter?ctx $=851 \mathrm{e} 102 \mathrm{ca} 25 \mathrm{~b} 8 \mathrm{f} 80242 \mathrm{~d} 388 \mathrm{~d} 8110 \mathrm{af} 4 \mathrm{ca} 376 \mathrm{c} 4 \mathrm{~b} 1 \& \mathrm{idx}=51$

Hoover Institution. (2021h). Bilgi konulu propaganda posteri. https://digitalcollections.hoover.org/objects/40322/knowledge-wins-public-library-books-arefree?ct $=584 \mathrm{ddab} 6 \mathrm{c} 0 \mathrm{ef} 2 \mathrm{ac} 63409610225 \mathrm{c} 4465 \mathrm{fcdfde} 01 \mathrm{~d} \& \mathrm{idx}=83$ 
Hoover Institution. (2021i). Cephe konulu propaganda posteri. https://digitalcollections.hoover.org/objects/40083/united-warwork?ctx=3a2b0acc80be995cc508a587dcb1113ccec23c39\&idx=104

Hoover Institution. (2021j). Kamp konulu propaganda posteri. https://digitalcollections.hoover.org/objects/40452/the-camp-library-is-yours-books-forfighting-men-at-your-ca?ctx=cbb78d3fe17f07064d7b0ea1c3e5f08fe1b8ca66\&idx=2

Işık, M. ve Karaca, M. (2019). Vichy Fransası'nda müttefik devletlerine karşı yürütülen propaganda faaliyeti. Anadolu Akademi Sosyal Bilimler Dergisi, 1(3), 43-62.

Jankowska, M. A. (2011). Going beyond environmental programs and green practices at the American Library Association. Electronic Green Journal, 1(32), 1-17.

Jones, B. M. (2015). 3D printing in libraries: A view from within the American Library Association: Privacy, intellectual freedom and ethical policy framework. Bulletin of the Association for Information Science and Technology, 42(1), 36-41. doi: 10.1002/bul2.2015.1720420113

Kniffel, L. (2020). Erişim Adresi https://americanlibrariesmagazine.org/2020/05/01/well-always-haveamerican-library-in-paris/

Latham, J. M. (2010). Clergy of the Mind: Alvin S. Johnson, William S. Learned, the Carnegie Corporations, and the American Library Association. The Library Quarterly, 80(3), 249-265. doi: $10.1086 / 652875$

LHB. (2021). ALA ve Birinci Dünya Savaşı. http://www.libraryhistorybuff.com/ala-ww1.htm

LHB CL. (2021). ALA - Kamp Kütüphaneleri. http://www.libraryhistorybuff.com/ala-ww1camplibraries.htm

LHB H. (2021). ALA - Hastane Kütüphanesi. http://www.libraryhistorybuff.com/ala-ww1hospital.htm

Library War Service. (2021). Kütüphane Savaş Servisi. Erişim Adresi http://www.ala.org/aboutala/1917

Marquis, A. G. (1978). Words as weapons: propaganda in Britain and Germany during the First World War. Journal of Contemporary History, 13(3), 467-498. doi: 10.1177/002200947801300304

Martin, R. S. ve Shiflett, O. L. (1996). Hampton, fisk, and Atlanta: The foundations, the American Library Association and library education for blacks, 1925-1941. Libraries \& Culture, 31(2), 299-325.

Maymí-Sugrañes, H. J. (2002). The American Library Association in Latin America: American librarianship as a "modern" model during the good neighbor policy era. Libraries \& Culture, 37(4), 307-338.

Messinger, G. S. (1992). British propaganda and the state in the First World War. The United Kingdom: Manchester University Press.

Messinger, G. S. (1993). An inheritance worth remembering: the British approach to official propaganda during the First World War. Historical Journal of Film, Radio and Television, 13(2), 117-127. doi: 10.1080/01439689300260161

Monger, D. (2012). Patriotism and propaganda in First World War Britain: The national war aims committee and civilian morale. Liverpool University Press.

Monger, D. (2014). Nothing special? Propaganda and women's roles in late first world war Britain. Women's History Review, 23(4), 518-542. doi: 10.1080/09612025.2014.894755

Olle, J. G. (1977). The Library Association and the American Library Association: Their first fifty years. Journal of Librarianship, 9(4), 247-260. doi: 10.1177/096100067700900401 
Preer, J. L. (2004). "This Year-Richmond!": The 1936 Meeting of the American Library Association. Libraries \& Culture, 39(2), 137-160.

Redley, M. (2007). Origins of the problem of trust: Propaganda during the First World War. Bakir, V. ve Barlow, D. M. (Ed.). In Communication in the age of suspicion (ss. 27-38). Palgrave Macmillan. doi: 10.1057/9780230206243_3

Rifat, M.(2013). Açıklamalı göstergebilim sözlügü̈: Kavramlar, yöntemler, kuramcılar, okullar. Türkiye İş Bankası Kültür Yayınları.

Robertson, E. (2014). Propaganda and 'manufactured hatred': A reappraisal of the ethics of First World War British and Australian atrocity propaganda. Public Relations Inquiry, 3(2), 245-266. doi: $10.1177 / 2046147 \mathrm{X} 14542958$

Sanders, M. L. (1975). Wellington House and British propaganda during the First World War. The Historical Journal, 18(1), 119-146.

Sanchez, B. A. (2005). United States v. American Library Association: The choice between cash and constitutional rights. Akron Law Review, 38(2), 463-502.

Shover, M. J. (1975). Roles and images of women in World War I propaganda. Politics \& Society, 5(4), 469-486. doi: 10.1177/003232927500500404

Smith, A. K. (2003). The pankhursts and the war: Suffrage magazines and First World War propaganda. Women's History Review, 12(1), 103-118. doi: 10.1080/09612020300200349

Sperry, C. (2014). Looking at World War I propaganda. Social Education, 78(5), 235-240.

Sroka, M. (2019). The American Library Association and the post-World War II rebuilding of Eastern European libraries. IFLA Journal, 45(1), 26-33. doi: 10.1177/0340035218793920

Sullivan, P. (1996). Carnegie fellowships for librarians 1929-1942: A microcosm of Carnegie Corporation and American Library Association joint enterprise. Libraries \& Culture, 31(2), 437-446.

Taylor, P. M. (1980). The foreign office and British propaganda during the First World War. The Historical Journal, 23(4), 875-898.

Tunc, T. E. (2012). Less sugar, more war ships: Food as American propaganda in the First World War. War in History, 19(2), 193-216. doi: 10.1177/0968344511433158

Wang, J. (2007). Telling the American story to the world: The purpose of US public diplomacy in historical perspective. Public Relations Review, 33(1), 21-30. doi: 10.1016/j.pubrev.2006.11.005

Wiegand, W. A., ve Wadsworth, S. (2010). By invitation only: The American Library Association and the Woman's Building Library of the World's Columbian Exposition, Chicago, 1893. Signs: Journal of Women in Culture and Society, 35(3), 699-722. doi: 10.1086/649043

Wiegand, W. A. (2017). “Any ideas?”: The American Library Association and the desegregation of public libraries in the American south. Libraries: Culture, History, and Society, 1(1), 1-22. doi: 10.5325/libraries.1.1.0001

Wilkin, B. (2014). Aviation and propaganda in France during the First World War. French History, 28(1), 43-65. doi: 10.1093/fh/crt084

Williams, B. F., Charney, M., ve Smith, B. (2015). Growing our vision together: Forming a sustainability community within the American Library Association. Sustainability: Science, Practice and Policy, 11(2), 57-69. doi: 10.1080/15487733.2015.11908147

Witt, S. (2017). The evolution of privacy within the American Library Association, 1906-2002. Library Trends, 65(4), 639-657. doi: 10.1353/lib.2017.0022 
Yee, M. M. (2009). "Wholly visionary": the American Library Association, the Library of Congress, and the card distribution program. Library Resources \& Technical Services, 53(2), 68-78.

Young, A. P. (1980). Aftermath of a crusade: World War I and the enlarged program of the American Library Association. The Library Quarterly, 50(2), 191-207. doi: 10.1086/600960 